1975

\title{
Archaeological and Historical Resources in the San Antonio- Guadalupe River Basins: A Preliminary Statement
}

Thomas R. Hester

Center for Archaeological Research

Follow this and additional works at: https://scholarworks.sfasu.edu/ita

Part of the American Material Culture Commons, Archaeological Anthropology Commons, Environmental Studies Commons, Other American Studies Commons, Other Arts and Humanities Commons, Other History of Art, Architecture, and Archaeology Commons, and the United States History Commons

Tell us how this article helped you.

This Article is brought to you for free and open access by the Center for Regional Heritage Research at SFA ScholarWorks. It has been accepted for inclusion in Index of Texas Archaeology: Open Access Gray Literature from the Lone Star State by an authorized editor of SFA ScholarWorks. For more information, please contact cdsscholarworks@sfasu.edu. 


\section{Archaeological and Historical Resources in the San Antonio-Guadalupe River Basins: A Preliminary Statement}

\section{Creative Commons License}

\section{(c) (1) \&}

This work is licensed under a Creative Commons Attribution-NonCommercial 4.0 International License 
ARCHAEOLOGICAL AND HISTORICAL RESOURCES

IN THE SAN ANTONIO-GUADALUPE RIVER BASINS:

A PRELIMINARY STATENENT

Assembled by

Thomas R. Hester

Center for Archaeological Research

The University of Texas at San Antonio

Regional Studies, No. 1

1975 
TABLE OF CONTENTS

Page

Introduction ....................... 1

Archaeology of the Study Area .............. 2

Blbliography of Archaeology in the Study Area. . . . . 25

A General Overview of Indian Cultures ............ 43

Historical Summaries of Counties in the Study Area. . . . 51

General Comments on Ethnic and Religlous Groups of

the Region....................6 60

Architecture and Styles................. 62

Concluding Comments . . . . . . . . . . . . 67

Bibliography. . . . . . . . . . . . . . . 68 


\section{IIST OF FIGURES}

FIGURE

PAGE

1. Recorded Archaeological Sites in the Study Area.

2. Locations of Proposed Dams and Reservoirs in the Study Area.

3. Approximate Locations of Major Indian Groups in the Study Area During the Sixteenth and Seventeenth Centuries.

4. Locations of Major Indian Groups in the Study Area During the Eighteenth and Nineteenth Centuries.

5. Locations of Significant Architectural Resources in 66 the Study Area.

\section{TABLE}

1. Types of Archaeological Sites in Counties Within the 14 Study Area. 


\section{INTRODUCTION}

In November, 1974, the Center for Archaeological Research of The University of Texas at San Antonio was requested to prepare an archaeologica1-historical resource inventory of the Guadalupe-San Antonio River Basins. This work was done under contract with Ecology Audits, Inc of Dallas, Texas. The contract called for the inventory to be of a general nature, suitable for use as a base line description in planning. The contract stated that the following items were to be included in the assessment:

1) Inventories for the 15 counties within the basin: Bandera, Bexar, Caldwe11, Calhoun, Coma1, DeWitt, Goliad, Gonzales, Guadalupe, Hays, Karnes, Kendall, Kerr, Victoria, and Wilson Counties, as well as two counties, Medina and Uvalde, lying outside the study area.

2) Topics including, but not limited to:

a. Statements about archaeological sites and their significance

b. Indian cultures

c. Other ethnic cultures

d. Religious groups

e. "Western Frontier"

f. Architecture and styles

g. Major historical events

h. Major historical persons

3) General Assessment of archaeological and historical resources in the following proposed reservoirs:

a. Lockhart Reservoir (Gonzales County)

b. Cloptin Crossing Reservoir (Hays County)

c. Goliad Reservoir (Goliad and Karnes Counties) 


\author{
d. Applewhite Reservoir (DeWitt County) \\ e. Cuero Reservoir (DeWitt County) \\ f. Ingram Reservoir (Kerr County).
}

This report presents the results of the study carried out by the Center for Archaeological Research. Active participants in various phases of the project included the following Center personnel: Feris A. Bass, Jr., Mary Frances Chadderdon, Nancy Y, Clayton, Anne A. Fox, E. S. Harris, Cheryl Lynn Highley, Jules Jacquier, Thomas C. Kelly, and Harvey P. Smith, Jr.

\title{
ARCHAEOLOGY OF THE STUDY AREA*
}

From the time when public interest was first attracted to the prehistory of the state in the late 19th century, up to the middle of this century, most of the work of finding and recording archaeological sites in this region has been done by amateur archaeologists, with help and guidance from professionals on university and museum staffs. The mid-20th century plan for the Canyon Dam was the forerunner of a growing number of engineering projects which called for large-scale archaeological surveys, and marked the beginning of the era of these surveys in the San Antonio-Guadalupe River basins. A product of such a survey is a mass of data on a group of sites which will be of primary interest to students and scholars. For many years the results of these surveys, as well as the data recorded by various interested amateur archaeologists around the state, have been filed at the Texas Archeological Research Laboratory in Austin, where the University of Texas at Austin operates a central clearing house of files and artifacts, as well as an on-going program of preservation and research. In order to be recorded, a site must be located, examined, plotted on a map, and reported; this is time-consuming and thus a very small percentage of the existing sites in most areas have been documented. The exceptions to this are where intensive professional surveys have been done and published, and where dedicated amateurs have spent a great deal of time in survey efforts carefully recording their findings.

Chronology

The archaeology of Texas has been tentatively divided into a number of time periods. The earliest, the paleo-Indian period (late Pleistocene; 9200 - 6000 B.C.), was a time in which there was at least some degree of dependence on large game animals, including mammoth and a now-extinct species of bison. Evidence of this early period consists of various types of distinctive fluted and lanceolate projectile points, usually exhibiting fine workmanship. A small number of these sites has been reported in the areas under discussion.

*Compiled by Anne A. For and Thomas $R$. Hester 
Later in time, the people of the Archaic period (6000 B.C. - A.D. $500 / 1000$ ) hunted modern species of game including deer and rabbit, and gathered edible roots, nuts, and fruits. A multitude of types of projectile points and tools of bone, stone and shell are characteristic of this period. By far, the largest number of sites reported in the study area fall into the Archaic.

By the time of the Neo-American period, (late prehistoric; A.D. $500 / 1000$ - A.D. 1500), a number of innovations were appearing, such as the bow and arrow, pottery, and in some parts of Texas, the beginnings of agriculture. There has been little indfcation that the prehistoric peoples of the San Antonio and Guadalupe River basins practiced agriculture. However, comparatively few Neo-American period sites have been carefully recorded or excavated.

The Historic period is marked by the arrival of Europeans and the subsequent impact on the aboriginal inhabitants. Many of the sites of this period are structures built by early settlers. As interest in local history and in historical archaeology is growing, more of these sites are being reported and examined. So far, a moderate number have been recorded in the area under consideration, and many more are undoubtedly present.

Types of Sites

Until the arrival of the early Spanish and Anglo-American settlers, the inhabitants of the San Antonio and Guadalupe River basins were small groups of semi-nomadic peoples who roamed portions of southern and south-central Texas in search of food, perhaps responding to the availability of game animals and the ripening seasons of the fruits and nuts upon which they depended. By far the majority of sites where the remains of these people can be found are open campsites on the surface or buried in river terraces, in rockshelters rimming the stream valleys, or in shell heaps near the coastal waters. Artifacts found in these sites, along with the ashes and fire-cracked stones from their hearths, are cutting, scraping and chopping tools of chert (flint) and occasional chert projectile points, as well as quantities of chips and flakes which result from their manufacture and repair. Also occasionally present are tools of bone, shell, and stone. Later aboriginal sites contain, in addition, sherds of pottery and, in the historic era, trade items such as glass beads and metal implements.

Associated with campsites in the upper reaches of the San Antonio and Guadalupe River valleys are mounds of fire-cracked 1imestone, some as large as one acre in size. The origin and use of these "burned rock middens" is still unknown (Hester 1971), although it is possible that they reflect a specialized method of food preparation.

Burials are occasionally found near or in conjunction with habitation sites, or in the sink holes or solution cavities which abound 
in the upper reaches of the river valleys (Collins 1970). A number of these burial sites have been recorded in the areas under discussion.

Another type of site reported is the quarry and/or workshop, located near a natural source of chert, either a ledge or nodular outcrop in upland areas, or a gravel deposit in the stream bank (see Patterson 1974; Hester, Bass and Kelly 1975). These sites are 1ittered with rejected chunks and large flakes which are derived from quarrying operations, and with the debris which resulted from roughing-out tools and projectile points to be carried back to campsites for finishing.

Sites of 18 th century Spanish missions and presidios are also present in the area. Built first of logs and thatch, these establishments gradually constructed stone buildings, often of remarkable sophistication. Many have recently been restored or stabilized; others are crumbling in the brush, known only to landowners, historians, and archaeologists.

Eighteenth century Spanish ranches and ear1y 19 th century Ang10American homes and cemeteries are scattered along the river valleys. Often a home was built over an early prehistoric campsite, showing that man's requirements for a good place to live have not changed greatly over the centuries.

\section{COUNTY SUMMARIES}

Bandera County contains the headwaters of the Medina River, a major tributary of the San Antonio River and the source of the Sabinal River, and lies over a portion of the Edwards aquifer. Of eight archaeological sites recorded, all contain burned rock middens, and one includes an open campite as well. All but one of these sites are located in the upper reaches of creeks which flow into the Medina River. The other site is on the Medina, just west of the town of Bandera. No professional surveys or excavations have been carried out in the county. Judging from sites recorded in adjacent areas, the number of recorded sites is not an accurate reflection of the archaeology of the county. Sites containing burned rock middens, open camp sites, rock shelters and quarry/workshop sites can be predicted to exist throughout the county, concentrated particularly on river terraces along the Medina and up the valleys of its major tributaries. These would range from Paleo-Indian to Neo-American times, as sites containing Neo-American pottery have been described although not formally recorded in the area. In historic times the Bandera Pass is thought to have been the site of an Apache village, and there have been stage stations and military encampments throughout the county, not to mention early settlers' cabins and settlements. A great deal more information is needed on the location and dating of all these types of sites. Virtually nothing is known of the archaeology of the Sabinal River in Bandera County, although the river valley contains a number of important archaeological sites farther south in Uvalde County. 
Bexar County encompasses the headwaters of the San Antonio River and Salado, Olmos, and Leon Creeks. Near its southern boundary is the Medina River, an important tributary, and on its northern boundary is Cibolo Creek which joins the San Antonio River farther south in Karnes County. The northern portion of the county overlies the Recharge Area of the Edwards aquifer. Bexar is probably the most-studied county, archaeologically, in south-central Texas. At least seven major surveys and 14 professional excavations have been carried out, contributing to the total of 226 sites presently recorded.* Prehistoric sites are predominantly open campsites on river terraces, with chert workshop/ quarry sites, burned rock middens, and a sma11 number of rockshelters. Time periods represented range from Paleo-Indian to Neo-American, the majority being of the Archaic period. Forty-three historic sites have been recorded, including 18 th century Spanish missions and related structures and 19 th century homes, burial grounds, lime kilns, and grist mills.

Despite the number of sites recorded and the archaeological work done in Bexar County, it is apparent that there are large sections about which very little is known. One such area falls within the proposed Applewhite Reservoir on the Medina River, which should contain many important prehistoric sites. Submissions to the National Register of Historic Places from Bexar County include:

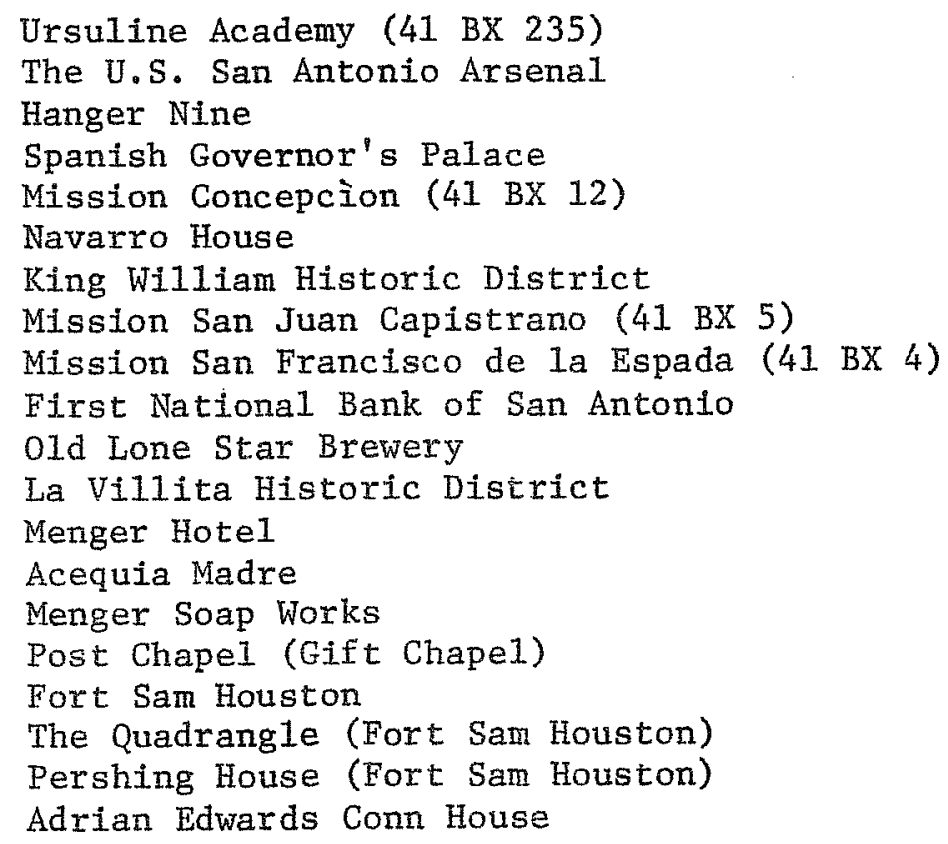

Caldwell County contains the central section of Plum Creek, a tributary of the San Marcos River which forms the county's southern boundary. The Lockhart dam site is located on Plum Creek within the county. Ten archaeological sites have been recorded in Caldwell

*301 sites had been recorded by late 1975 . 
County, all open campsites of Archaic times, although one site appears to have also had Paleo-Indian and Neo-American components. No professional archaeological surveys or excavations have been done.*

Considering its geographical location at the edge of the Edwards Plateau, the presence of major water sources, and the density of sites in neighboring Guadalupe County, it is reasonable to predict that prehistoric sites are numerous on terraces near PIum Creek and the San Marcos River. Caldwell County was settled in the early 19th century, and early settlements and homesites undoubtedly exist which have not been recorded. We have been told there are historic Indian campsites and battle sites in the area and these should be located and recorded.

One historic Iandmark, the Emmanuel Episcopal Church, has been nominated to the National Register of Historic Places.

Calhoun County is bounded on the southwest by the lower portion of the Guadalupe River, including its confluence with the San Antonio River and the point where the Guadalupe River enters San Antonio Bay. It is bounded on the southeast by Espifitu Santo Bay and contains Lavaca Bay and several smaller bays to the northeast. Fifty archaeological sites have been recorded, and one professional survey has been done (Fritz 1972). The sites are predominantly open campsites of the Archalc and Neo-American time periods, located on she11 middens on river terraces or on bluffs overlooking the bays. So far five 19th century towns or homesites have also been recorded.

Archaeological sites on areas bordering the bays are eroding rapidly, and of many large sites originally recorded in the early part of this century, only a trace remains today. However, a great deal of the area farther inland surrounding the tributaries and portions of the main channel of the Guadalupe have never been surveyed. Of particular interest are campsites of the historic Indian tribes and early Spanish sites which are known to exist somewhere in the area and which should be located and recorded. The fact that Calhoun County was a center for coastal shipping throughout the 19 th century means that remains of early towns and settlements exist whose location is known but whose remains have never been officially recorded and examined.

* Subsequent work in Caldwell County has been reported by Thomas $\mathrm{R}$. Hester, Thomas C. Kelly, and Feris A. Bass, Jr., An Initial Archaeological and Historical Assessment of Three Proposed Dam Sites in Gonzales and Kenda11 Counties, Texas, Regional Studies, No. 2, The Center for Archaeological Research. The University of Texas at San Antonio, February, 1975. 
Comal County contains a section of the upper Guadalupe River and is bounded on the south by the upper reaches of Cibolo Creek, a major tributary of the San Antonio River. Fifty-four archaeological sites have been recorded in the county, of which the majority are open campites, although a variety of other types are present, including burned rock middens, shelters, and burials.* All of these sites date to the Archalc and Neo-American periods. They occur primarily on river terraces overlooking the Guadalupe and its major tributaries, and many have now been inundated by Canyon Reservoir. One 19th century German site has also been recorded. Two professional surveys have been done, one of Canyon Reservoir in 1949 which accounts for the majority of the recorded sites in the county (Stephenson 1949). In 1963 a survey of Blieders Creek, a smal1 tributary of the Guadalupe, recorded four sites (Shafer n.d.). Several professional excavations have been done in the Canyon Reservoir (Johnson, Suhm, and Tunnell 1962).

Judging from the number of archaeological sites recorded within the reservoir areas where a concerted effort has been made, it is reasonable to expect that the Guadalupe River and its tributaries and Cibolo Creek to the south will contain numerous sites, both prehistoric and historic, which are worthy of recording and of further study. The presence of many sink holes, features known to have been used as burial sites, may provide information on prehistoric mortuary practices. Farms and settlements of early 19 th century German imigrants are scattered throughout Comal County and deserve further documentation and investigation.

Submissions to the National Register from Comal County are:

First Protestant Church, United Church of Christ Lindheimer House Stephen Klein House

Dellitt County contains a section of the central portion of the Guadalupe River as well as Sandies Creek, one of 1 ts tributaries. A total of 223 archaeological sites has been recorded, the mafority being the result of two professional surveys which included parts of the county. A survey of the proposed Cuero Reservoir recorded 212 sites (Fox et al 1974) and a survey of a section of the Ecleto Creek watershed recorded an additional site (Crawford 1971). Most of the sites date from the Archaic period, although one site contained a Paleo-Indian component and a number yielded Neo-American artifacts, indication that all prehistoric periods are represented. These are open campsites, located on terraces of the major streams and their tributaries. A large number of historic sites are also

*As of late 1975, 89 sites had been documented. See Thomas C. Kelly and Thomas R. Hester, Archaeologica1 Investigations at Four Sites in the Dry Comal Watershed, Comal County, South Central Texas, Center for Archaeological Research. The University of Texas at San Antonio, Archaeological Survey Report, No. 15, 1975. 
located in DeWitt County, due to its history as an early Anglo colony and the influx of later immigrants who followed the opening of the area to settlement.

From the number of archaeological sites recorded in an intensive survey of one section of the Guadalupe, it may be presumed that a similar situation exists throughout Dewitt County and that only a small percentage of the total existing prehistoric sites have been recorded. There is also the potential for study of settlement patterns in historic times in this county.

The Cuero I Archaeological District and the Dewitt County Courthouse have been nominated to the National Register of Historic Places.

Goliad County contains a portion of the lower San Antonio River and two of its major tributaries. Nine archaeological sites have been recorded, about half of which are open campsites of Archaic and NeoAmerican age (Hester and Parker 1970) and the other ha1f, 18th century Spanish structures.* of the latter, four have been the scene of major professional excavations beginning in the $1930^{\prime} \mathrm{s}$ and continuing up to the present day.

Due to the lack of knowledge of the prehistoric sites in the area, a great deal more needs to be done in terms of survey and analysis. The location of the proposed Goliad Dam near the center of the county should provide an excellent opportunity for an intensive site survey. A number of 18 th century Spanish trails and ranches are known to have existed within Goliad County. Sites of these and later 19 th century settlements are probably located within or near the major stream drainages.

Submissions to the National Register from Goliad County are:

01d Market House

Mission Nuestra Señora del Rosario de los

Cujanes (41 GD 2)

Gonzales County contains a part of the center section of the Guadalupe River and two major tributaries; the San Marcos River and Peach Creek, as well as a section of Sandies Creek to the south. The proposed Gonzales Dan is located on the San Marcos River in the center of the county. One hundred and forty-six archaeological sites have been recorded. A major survey of the proposed Cuero Reservoir accounted for 140 of the total (Fox, et al. 1974). These sites are predominantly prehistoric campsites, of Paleo-Indian to Neo-American

*A number of additional archaeological sites have been documented during University of Texas at San Antonio's survey along the Gollad County side of Coleto Creek. 
age, located on stream terraces. Twenty-five early 19 th century homesites have also been recorded.

The number of sites located by the Cuero Reservoir survey gave an indication of the potential for future archaeological work on the major streams of the county, and probably also on the smaller tributaries. A number of historic sites, including settlements, homesites, reputed Indian camps, early forts (such as Fort Wahl at Gonzales; Orchard ms.) and battle sites are known to exist, but most have not yet been recorded.

\title{
Submissions to the National Register from Gonzales County are:
}

Cuero I Archaeological District

Braches Home

Gonzales County Court House

Kennard House

Guadalupe County contains a section of the central portion of the Guadalupe River. Its northern boundary is the San Marcos River, part of its southern boundary is Cibolo Creek, and Ecleto Creek begins in the southern section. Only seven archaeological sites have so far been recorded in the county, of which four are campsites of Archaic and Neo-American times and three are 19th century pottery kiln sites. No professional archaeological surveys or excavations have been done, which undoubtedly accounts for the small number of documented sites. The location of the historic town of seguin within the county should be an indication that many more 19th century sites are present.

\section{Submissions to the National Register from Guadalupe County are:}

\author{
Hollamon House \\ Los Nogales \\ Sebastopo1 (Zorn House)
}

Hays County contains the central portion of the Blanco River, a tributary of the San Marcos River which flows into the Guadalupe. The proposed Cloptin Crossing Dam site will cross the Blanco in the southern part of the county. The eastern half of Hays County overlies the Recharge Area of the Edwards aquifer. Ninety-four archaeological sites have been recorded in all sections of the county, of which approximately three-fourths are prehistoric campsites, burned rock middens, or quarry/workshops, all located on terraces near the major streams and their tributaries.* These are all of Archaic age, although six sites also had Neo-American components. The high

* Since this report was prepared, the Southern Texas Archaeological Association has documented and investigated several additional sites near Wimberley, in Hays County. One of these sites is a rockshelter (41 HY 95) with Neo-American and Archaic deposits. 
proportion of historic sites recorded is due to a thorough survey of an extinct rural 19 th century community in the north-central part of the county in 1971-72 (Roberson 1972). Judging from the results of this survey, the possibility is strong that other similar unmarked and long-forgotten settlements could exist in many areas of the Hill Country. A survey of the headwaters of the San Marcos River in 1974 recorded 22 prehistoric sites within an area of five square miles (Patterson 1974). Results of these surveys indicate that the archaeological potential of Hays County is extensive and much of it is as yet unknown and unrecorded.

Nominations to the National Register of Historic Places from Hays County are:

First United Methodist Church Koch House

Karnes County contains part of the central section of the San Antonio River including its confluence with Cibolo and Ecleto Creeks. The sites of the proposed Ecleto and Falls City Dams are within the county. However, most of the area affected by the latter dam lies in Wilson County. Twenty-six archaeological sites have been recorded of which the majority are open campsites buried in or on the surface of alluvial stream terraces. These date from Paleo-Indian to NeoAmerican times. One 19th century historlc site has been recorded. Most of the recorded sites were located by a professional survey done in 1970 on Ecleto Creek (Crawford 1971).

A great deal more information is needed on the location and identification of archaeological sites in this county. The fact that a survey of a portion of a small tributary creek near Kenedy (Fox 1974) revealed a complete absence of sites on that stream raises questions which can be answered only by more extensive surveys. A number of 19th century Spanish trails and ranches and early 19 th century Anglo-American settlements are known to have existed in Karnes County. The locations and extent of these remains need to be documented.

Kendale county contains a portion of the upper Guadalupe River watershed. Cibolo Creek, which flows southeast to join the San Antonio River. The Blanco River, a tributary of the Guadalupe, originates in the county, and the northern part of the county overlies the Edwards aquifer. A total of 23 archaeological sites have been recorded, of which approximately half are open campsites and the other half, burned rock middens. Two occupations in rockshelters have also been recorded. These sites date from the Archaic to Neo-American periods. Sites are located on terraces overlooking the major streams or in the upper reaches of tributaries. No professional surveys or excavations have been carried out in Kendall County, and a comparatively small percentage of the potential number 
of sites has been recorded.* The type of site in this area about which the least is known and which holds the greatest promise of recovery of important data is the rockshelter. These features may contain preserved perishable materials and, occasional1y, rock art in the form of pictographs on the walls. Because of the geology of the county and its location on the edge of the Edwards Plateau, the potential for finding more shelter sites is great and should be actively pursued. Also of importance in the area are early 19 th century historic sites, where German settlers first farmed the river valleys, and the campsites of early historic Indian groups.

Kerr County contains the headwaters of the Guadalupe River and a number of its more important tributaries, and the majority of the county overlies the Edwards aquifer. A total of 116 archaeological sites are recorded from Kerr County at the Texas Archeological Research Laboratory in Austin, and an additional 165 are recorded at the archaeological laboratory at Southern Methodist University, most dating from the Archaic period. The predominant type is the burned rock midden. Sites are located on or near terraces overlooking the Guadalupe River and its major tributaries. Two major professional surveys have been carried out in the county. In 1970 a survey of the Ingram Reservoir recorded 62 sites in the northwestern part of the county (Briggs 1971). In 1971 and 1972 extensive surveying and testing was done by the Texas Archeological Society in the Turtle Creek Area, south and west of Kerrville, in which 165 sites were recozded (Skinner 1974). Judging from the large number of sites found wherever intensive survey work has been done, it is apparent that nearly every stream in Kerr County is 1ikely to be dotted with campsites and burned rock middens, of which only a small percentage have been recorded. It is also possible that pictographs may exist within the county, as a number of sites containing them have been reported in surrounding counties (Jackson 1938). The early 19 th century German settlers' farms and settlements in the southeastern part of the county have not as yet been properly traced and recorded. Campsites of the historic Apache and Comanche intruders undoubtedly exist, none of which have yet been located.

The only submission to the National Register from Kerr County is historic Camp Verde (41 KR 111).

Medina County contains the central portion of the Medina River, a major tributary of the San Antonio River, and is bisected by Hondo Creek. The northern part of the county overlies the Recharge Area

*Recent activity by the Center for Archaeological Research in the Upper Cibolo Watershed in Kendall County has led to the documentation of over 40 additional archaeological sites (Bass and Hester 1975). Subsequent studies of sites in this vicinity have yielded abundant evidence of early Archaic occupations (Kelly and Hester, ms. in preparation). 
of the Edwards aquifer. Eight archaeological sites, dating from Paleo-Indian to Neo-American times, have been recorded in the northern part of the county, including an open campite, a burial site, burned rock middens, a rockshelter, a quarry site, and a 19 th century historic site. No professional surveys or excavations have been done.

Amateur archaeologists and relic collectors have reported the existence of numerous prehistoric sites along the Medina River and Hondo Creek which have never been properly recorded. Several 19 th century settlements and numerous historic buildings are known which have not been studied or recorded. Campsites of historic Indian tribes in the area have not yet been identified and documented.

Submissions to the National Register include:

Castroville Historic District

Landmark Inn Complex:

01d D'Hanis Historic District

Uvalde county contains portions of the Sabinal, Frio, Leona, and Nueces Rivers, and overlies the Recharge Area of the Edwards aquifer. The Sabinal, Concan, and Montell Dan sites have been proposed for the northem part of the county. Sixty-seven archaeological sites have been recorded, of which approximately half are open campsites or shelters and the remainder, middens, all dating from Paleo-Indian to Neo-American times. One sinkhole burial site and a number of quarry/workshop sites have also been recorded, as well as a 19 th century frontier fort. A professional survey in 1973 on the Leona River recorded 11 sites (Ha11 1974). Major excavations have been done at the Kincaid Shelter on the Sabinal River, (unpublished), at the La Jita site (a burned rock midden complex on the Sabinal River in the northeastern part of the county, Hester 1971), and at sites near the Nueces River southwest of Uvalde (Texas Highway Department, summer and fall, 1975).

Judging from the number of active streams in the county and its location on the edge of the Edwards Plateau, a large number of archaeological sites can be predicted to exist where none have yet been recorded. Although Uvalde County is not one of the areas where early settlements may be found (the town of Utopla, founded in the $1850^{\prime} \mathrm{s}$ as Waresville, is an exception), 1ittle is known of 17 th and 18 th century Spanish and Indian groups who lived in or travelled through the region and who may well have left recognizable traces of their activities.

*Excavations at the Landmark Inn were conducted by the Texas Historical Comission in sumer, 1975. 
Victoria County contains a section of the lower portion of the Guadalupe River and its southern boundary is the San Antonio River. Thirty-six archaeological sites have been recorded, including open campsites, and burial sites (spanning the Paleo-Indian, Archaic, and Neo-American periods), and 18 th century structures. No professional surveys have been done as yet in Victoria County, as reflected in the small number of sites on record.* However, very useful site surveys have been conducted by local amateur archaeologists. Three professionally-run archaeological excavations have been done. In 1938-40, the University of Texas excavated the Morhiss Site (Campbe11 1962). The Texas Memorial Museum tested the proposed site of La Salle's Fort St. Louis on Garcitas Creek in 1950, and in 1967, Texas Archeological Soclety carried out testing of the proposed second site of Presidio Loreto north of Victoria.

The only submission to the National Register of Historic Places from Victoria County at the time of this writing is Fort St. Louis (4 VT 4).

Wilson County contains a part of the center portion of the San Antonio River, as well as part of Cibolo and Ecleto Creeks. The site of the proposed Cibolo Dam is within the county. Sixty-one archaeological sites have been recorded, of which 57 are campsites of the Archaic and Neo-American periods, three are 19 th century potters' kilns, and one is an 18th century Spanish ranch headquarters. A professional archaeological survey was carried out on the Cibolo Creek in 1967 (Hsu and Ralph 1968).

Outside of the Cibolo Reservoir area, little is known of the prehistory of Wilson County. Judging from data available for surrounding counties, there should be many prehistoric sites on stream terraces of the San Antonio River and its major tributaries. There were a number of 18 th century Spanish ranches and trails within the county as well as early Anglo-American settlers' homes, most of which have never been located and recorded.

To date, the only submission to the National Register from the county is historic Rancho de las Cabras (41 WN 30).

*In 1975, the Center for Archaeological Research carried out an archaeological survey of Coleto Creek, and numerous new sites were documented (For and Hester, ms. in preparation). 
点

Bandera

Bezar

Caldwel1

Calhoun

ComaI

DeWitt

Goliad

Gonzales

Guadalupe

Hays

Karnes

Kenda11

Kerr

Medina

Uvalde

Victoria

Wilson
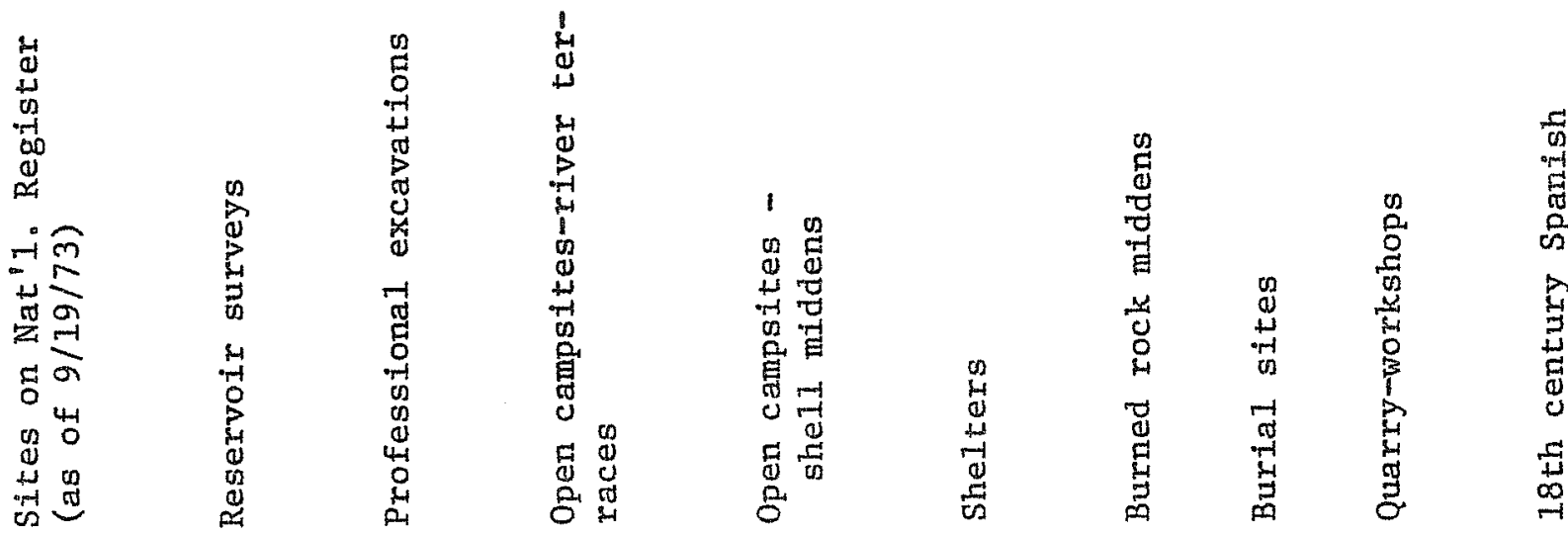

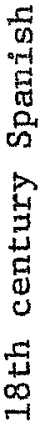

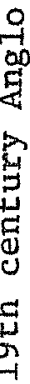

8

263

10

50

54
223

223
9

146

7

94

26
23

116

8

67

36

61

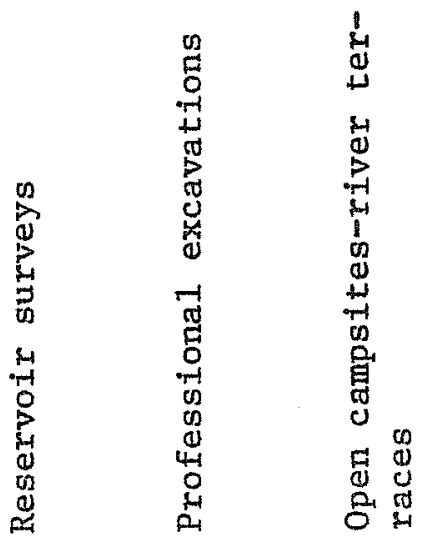

1

142

10

3
24

174

4
121

4
19

20

9

1

18

2

30

41

$\begin{array}{rrrrr}6 & 8 & 10 & 3 & 17\end{array}$

2

11

2

1

1

4

$\begin{array}{rrrr}1 & 25 & & 26 \\ & & & 3 \\ 2 & 11 & & 1 \\ & 102 & & 4 \\ 1 & 2 & 1 & 1 \\ 6 & 26 & 1 & 4\end{array}$

5

TABLE 1.

Types of Archaeological Sites in Counties within the Study Area

Compiled January, 1975. 


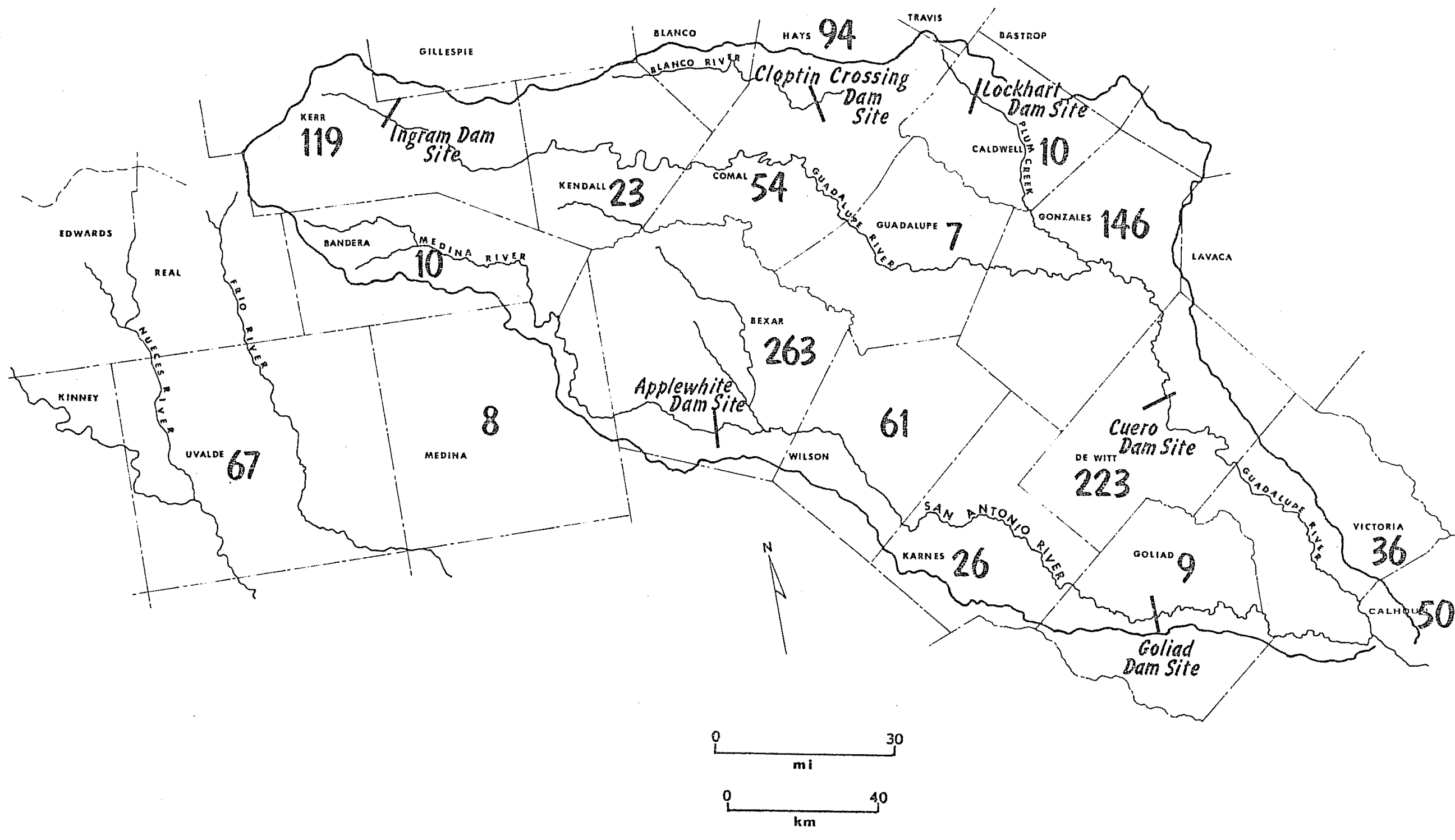

Figure 1. Recorded Archaeological Sites in the Study Area. The number of reported sites for each county is indicated (as of January 1975). 
Assessment of Resources in Proposed Reservoir Areas

As stated in the introductory section, part of the study of the San Antonio-Guadalupe River Basins involved a preliminary assessment of archaeological and historical resources in six proposed reservoir areas: Lockhart, Cloptin Crossing, Goliad, Applewhite, Cuero, and Ingram.

In two instances, the Cuero and Ingram Reservoirs, previous archaeological and historical surveys had been conducted. The results of these surveys are summarized in the following pages. However, within the boundaries of the four other proposed reservoir projects, no organized archaeological or historical investigation had been done. Since our task was to provide a general assessment, no extensive field operations were undertaken. Field teams from the Cencer paid brief visits to the areas of these four reservoirs, and in all cases, reported the presence of archaeological and historical resources. We have provided here only a brief summary of what has been done--or in most cases, what has not been done-in terms of archaeological-historical inventory in the reservoir areas. We believe that it is essential for an intensive archaeological-historical assessment to be carried out during the planning phases of these reservoir projects.

\section{Ingram Reservoir}

An archaeological survey of the area to be affected by the proposed Ingram Reservoir, Kerr County, Texas, was conducted in July and August, 1970 by the Archeological Division of the Texas Historical Survey Comittee under contractual agreement with the Texas Water Development Board. Summarized here is the report of that survey, authored by Briggs (1971).

The area to be inundated by the proposed reservoir lies within the drainage system of the Upper Guadalupe River Basin on Johnson Creek, an important tributary which joins the Guadalupe River near Ingram, Texas. A Iiterature search was conducted and information gathered on previously recorded sites in the area and its environs. The survey was conducted on foot and by vehicle. Sixty new sites were recorded, as we11 as three previously known, but undocumented, localities. Any area revealing indication of aboriginal habitation, regardless of its extent, was declared a site and so recorded. Inability to obtain entry permission from some landowners precluded the examination of the entire area.

Three main types of sites were recorded: flint (chert) quarries $(4.8 \%)$, open campsites strewn with fire-fractured limestone, flakes and artifacts $(25.4 \%)$, and campsites with burned rock middens $(69.8 \%)$. The burned rock midden sites consist of flat to slightly conical, circular to oval features, composed of a dense accumulation of burned rock, charcoal-stained, ashy soil, some animal bone remains, artifacts and broken flint, surrounded by scatters of 


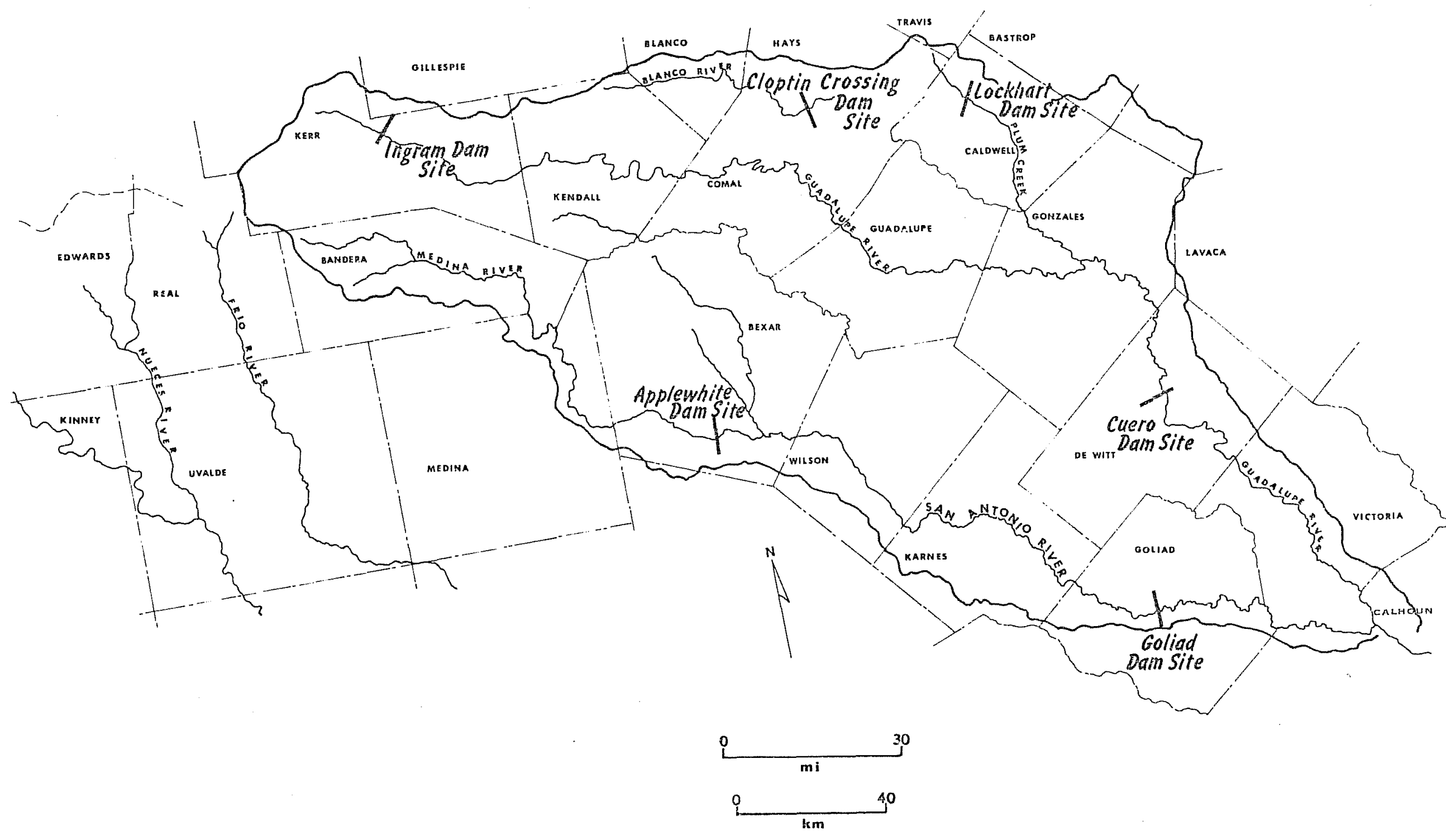

Figure 2. Locations of Proposed Dams and Reservoirs in the Study Area. The approximate dam sites for Ingram, Cloptin Crossing, Lockhart, Cuero, Goliad, and Applewhite are shown. 
lithic debris. Fifty-five burned rock middens were recorded, in some cases with two or three found at a single site. Many have been raided by relic hunters, others disturbed or destroyed by road construction, building, or plowing. Only eight sites had features which were regarded as relatively intact.

A total of 3,115 lithic specimens, virtually all of chlpped stone, was collected from the surface of the 63 recorded sites. Categories include flakes, cores, marginally timmed flakes (mostly side or end scrapers), various bifaces, and projectile points. of the projectile points 53 specimens are dart points, of which most are fragmentary, and five specimens are arrow points. These timediagnostic artifacts, range in age from Late Paleo-Indian times (ca. 9000-7000 B.C. ), through the Archaic (5000 B.C.-A.D. 500), up to Late Prehistoric (Neo-American; A.D. 500-1500),

Artifacts recovered in 1934 from test excavations at two sites within the reservolr area were found to be of the same types and in about the same percentage, with the addition of two dart points considered to have been prevalent in the Early Archaic period.

Twelve of the 63 sites reported were recommended by Briggs (1971: 68-70) for extensive tescing or excavation, all contalning Archaic materials. All would be adversely affected by creation of the proposed reservoir.

\section{Cuero Reservoir}

Cuero I Reservoir is proposed for the Guadalupe River in south-central Texas. When completed it will inundate approximately 45 stream miles of the river. The dam site will be a short distance upstream from the confluence of the Guadalupe River and Sandies Creek. The purpose of this reservoix will be to regulate the flow for municipal and industrial water supplies, provide for 1 lood control, and for recreational facilities along the lower Guadalupe River.

The proposed dam will be 6.4 miles $(10.3 \mathrm{~km})$ long and will provide a conservation pool surface level of 41,820 acres $(17,074 \mathrm{ha})$, which will be expanded at flood control capacity to 57,400 acres $(23,239$ ha).

Because of the great scope of this project and its expected impact upon existing archaeological sites, a comprehensive archaeological survey was conducted during 1972 and 1973 to assess the extent of that threat. This survey was carried out by Daniel E. Fox, Robert J. Ma1louf, Nancy O'Malley, and William M. Sorrow (For et al 1974) under the auspices of the Texas Water Development Board and the Texas Historical Commission.

This survey consisted of an intensive surface inspection and a testing program at such points as time and money permitted. Over 250 man-days were expended in this field examination, which included 20 tést excavations. 
As a result of the survey, 357 archaeological sites were identified, recorded, and evaluated within the confines and on the periphery of the proposed reservoir.

Though some sites had been disturbed by relic-hunters, many buried sites were wel1 preserved. It was the opinion of the investigators that most sites contained important information concerning the technology, subsistence, and settlement patterns of the prehistoric societies that inhabited this area over a period of approximately 8,000 years.

The survey report indicates that approximately 23 months of salvage archaeology would need to be conducted prior to any action that might destroy these archaeological sites. The cost of these mitigation activities is estimated to be approximately 1.1 million dollars (For et al 1974: 269).

\section{Cloptin Crossing Reservair}

The Cloptin Crossing Reservoir is a proposed Guadalupe-Blanco River Authority project. It is designed to impound 60,000 ha at top conservation level and 102.8 ha under maximum flood control pool. The flood control pool would extend $17.6 \mathrm{~km}$ up the Blanco River from the dam site, which is located in Hays County $1.5 \mathrm{~km}$ south of the River Road junction with the North Fork Road in Pioneer Town. Pioneer Town is a resort/amusement area $1.8 \mathrm{~km}$ southwest of the River Road junction with Highway 12 in Wimberley.

The area below the dam is a developed tourist-vacation area and some retirement and vacation home development is going on upstream. None of the ranches along the survey area seem to be worked full time, and there are only a few fields still being cultivated.

Brief reconnaissance was conducted in early January, 1975, by Thomas C. Kelly along the north side of the Blanco from the dam to the Pleasant Valley crossing, $12.8 \mathrm{~km}$ along the North Fork Road from Pioneer Town. All open roads were driven, five $k m$ were walked along the river, and three accesaible fields were explored.

Four archaeological sites were found. They are briefly described below:

Site 1 (41 HY 101)

Granny Cowan's field north of the River Road is about 20 ha of fallow land with quantities of exposed chert cobbles. The field is on the second terrace above and about $450 \mathrm{~m}$ north of the Blanco River. A concentration of worked chert pieces was noted in the northeast quarter and a sample was collected. The artifact inventory consisted of spokeshaves, scrapers, utilized flakes, thick and thin bifaces, cores, an Archaic dart point base, and a burin or possible blade core. Scattered bumed limestone and chert was observed along with a few grinding stones and flake debris. The field was too disturbed 
by repeated plowing for any features to be readily observed.

Site 2 (41 HY 102)

Site 2 consists of two small burned rock middens. One is in the road in front of Granny Cowan's abandoned farm house. A road-grader has cut into it, leaving a cross section for examination. These are quantities of burned 1imestone rock, but no flake debris was found in the approximately 10 m diameter midden. The second midden is located $10 \mathrm{~m}$ south of the first and had been freshly trenched by relic collectors. It is $35 \mathrm{~cm}$ deep with $10 \mathrm{~cm}$ of sterile soil beneath it. The midden is about $10 \mathrm{~m}$ in diameter and contains buxned, black, greasy limestone. There was a scattering of artifacts in the area, consisting mainly of cores. Undoubted1y other artifacts have washed down into the Blanco River about $150 \mathrm{~m}$ south or have been picked up by tourists and collectors.

Site 3 (41 HY 103)

The site is a small knapping station on the second terrace above the Blanco River west of Fox Hollow and $100 \mathrm{~m}$ west of a new house. The site is a circular area of about $10 \mathrm{~m}$, containing a concentration of knapping debris. Artifacts were: a flake borer, two crude bifaces, an end scraper made on a blade, and two exhausted cores. The site was undisturbed on thin clay soil among oak and cedar.

Site 4 (41 HY 104)

The site is located on the first terrace on a large bend in the Blanco River $500 \mathrm{~m}$ east of a ford. It was the only site with any flake debris along $2.5 \mathrm{~km}$ of the river bend. The thin soil over limestone was severly eroded. Artifacts were: a gouge, two cores, a scraper, and a burned biface. This land belongs to Mr. Chester Franklin of Wimberley, who has been a collector for many years and who stated there were no additional sites on his property.

Our survey was of a highly superficial nature and it is entirely possible that important archaeological material is to be found in this area. For this reason it is recommended that, prior to any construction, an intensive survey be made.

\section{Lockhart Reservoir}

The proposed dam site is roughly parallel to and $200 \mathrm{~m}$ west of Highway 183, beginning $1.8 \mathrm{~km}$ north of the Lockhart city 1 imits. It is approximately $100 \mathrm{~m}$ below the confluence of E1m and Plum Creeks.

The land in both creek bottoms is a heavy, black gumbo soil, changing to reddish clay soil as the land rises between and outside the two creeks. A thick cover of grass is found on most of the black soil and repeated floods have heavily silted the bottom areas while eroding the surrounding hills. The higher and lighter solls are heavily covered with large pebbles of Edwards chert, red quartzite, and near hill tops, Uvalde gravels. The entire area was heavily 
cultivated in the past, but in recent times, grass and weeds have grown up and the land has been converted to cattle pastures.

Reconnaissance was made in early January 1975 by Thomas C. Re11y, alded by C. D. Orchard. All passable roads through the reservoir site were travelled by car and those areas not covered with dense grass were surveyed on foot. Three archaeological sites were found and specimens were collected.

Site 1 (41 CW 11)

The site is located on Elm Creek in a fallow, black gumbo field, $50 \mathrm{~m}$ west of the creek. Specimens consisted of 1 ithic material only, and the site was probably a small knapping station. The artifact inventory consisted of heavy cobble cores or choppers, cores from which large flat wide flakes had been removed, small spokeshaves, an unusual plano-conver, biface scraper/knife, an incomplete bifacially-worked stemmed and shouldered dart point modified on its distal end (presumably for use as a scraper), and two other bifaces. A11 were found in an area of approximately $10 \mathrm{x} 15 \mathrm{~m}$ and were undoubtedly scattered by repeated plowing.

Site 2 (41 CW 12)

The site is in a fallow field approximately $200 \mathrm{~m}$ east of Plum Creek. The reddish clay field is fllled with Edwards chert cobbles, and has a very sparse covering of weeds. The artifacts consisted of two heavy crude choppers, a "chisel" or gouge, a small exhausted core, a crude biface, and the distal fragment of a large knife or dart point. A11 lay in a circular area of about five $\mathrm{m}$ in diameter. All were made of Edwards chert except one chopper, fashioned of Uvalde gravel. An extensive search over the field failed to produce a single flake.

Site 3 ( $41 \mathrm{CW} \mathrm{13)}$

The site is an eroding fallow field across the road from the Polonia Cemetery, all that remains of an abandoned Polish village. The field is about 50 ha and is profusely 1ittered with large cobbles of Edwards chert. A random search of the field indicated an area of about two ha in the southwest corner which had a scatter of heavy core/chopper tools. Nine were picked up, eight with the cortex remaining on the butt end. One apparent multipurpose tool made on a large flake was found.

Although the Texas Archeological Research Laboratory in Austin has no reported sites from the area, this very brief reconnaissance of the Lockhart Reservoir produced evidence of three. It is recommended that an intensive archaeological survey of the projected reservoir basin be conducted.

\section{Applewhite Reservoir}

The dam site and impoundment area of the proposed Applewhite Reservoir are located on the Medina River south of San Antonio. 
The floodplain is bisected north and south by Highway 16, Applewhite Road is the east boundary and Interstate 35 is the approximate west boundary. Loop 1604 and Highway 1518 form the south boundary.

A cursory examination of the area was conducted by driving and walking over selected portions in ear1y January, 1975, with the intent of gathering general information and examining those areas considered most likely to have been utilized for occupation in historic and prehistoric times. Much assistance in this regard was recelved through interviews with local residents. The survey party was composed of Feris A. Bass, Jr., Mary Frances Chadderdon, and Harvey P. Smith, Jr.

The floodplain includes the major portion of Elm Creek and about $10 \mathrm{~km}$ of the Medina River. The dam site is approximately $2 \mathrm{~km}$ southeast of the confluence of the two streams. About half of the area is under cultivation. Pecan trees are dominant along the stream courses, with considerable live oak and much heavy brush. Mesquite and some live oak are found on the higher terraces.

Historic sites of interest include the Monk home and the Walsh Ranch Cemetery. Both of these are estimated to be about 100 years old. The Monk home was originally a one room unit with fireplace. It is constructed of local limestone and lime-adobe mortar.

The Walsh Cemetery appears to contain as many as 50 burlals and includes a chapel. The roof construction has collapsed and the waIls are in poor condition. Each of the four sides has an ornamental iron gate entrance. Mr. Ed Walsh, the ranch owner, informed us that the property is still in the hands of the orlginal Spanish grant landowner family and that the majority of the burlals in the closed cemetery are those of tenant farmers who formerly worked the land. Other landowners in the area reported the existence of an old fort on the south bank of the Medina, approximately 900 in west of the point where Highway 16 crosses the river. They also informed us of an old cemetery about the same distance east of the Highway 16 crossing and on the south bank of the Medina River.

Several prehistoric occupation zones were found within the floodplain. Near the Monk home, we observed scattered flaking debris and collected a basal fragment of a Montell projectile point. This aboriginal occupation is along the south side of Eln Creek about $.5 \mathrm{~km}$ above its confluence with the Medina.

A few scattered chert flakes were observed but not collected on the southwest headland of the confluence of the two streams. Both the north and south ends of the dam location were surveyed on foot. The south terminus showed no surface indication of occupation. Cultural materials were found at the north terminus, extending along the north bank of the Medina River just outside the normal flood plain.

Twenty-six chert flakes, a possible metate and mano, and the basal fragment of a triangular projectile point were found. This occupation appears to extend for some distance upstream beyond the survey 
area. Only 90 to $135 \mathrm{~m}$ of river frontage were examined on foot. This area definitely should be examined in later surveys.

Several other crossings of E1m Creek and the Medina were surveyed by auto with 1 Imited on-foot checks of the immediate ground on both sides. No further prehistoric occupation was observed. Although the strean banks are fairly steep and abrupt, the terrain is flat to rolling and the elevation is only 150 to $160 \mathrm{~m}$ above sea level. The soil in much of the surveyed area appears to be rich alluvium and there is a possibility that buried occupations would be revealed by excavation.

In summary, our brief inspection of the area indicates the presence of both prehistoric and historic resources within the area of the proposed Applewhite Reservoir. We strongly recomend that an intensive survey and assessment of archaeological resources be conducted during the planning of this project.

\section{Goliad Reservoir}

The proposed Goliad Reservoir is located on the San Antonio River north of the town of Goliad, and extends as far north as Kenedy in Karnes County. At this point the river runs through a moderately wide valley of alluvial soil, marked by old stream meanders and occasional ox-bow lakes. Alluvial terraces are nearly a11 under cultivation, with the slopes and upper terraces used for pasture land. Wherever the land has not been continuously utilized, a thick thorny underbursh quickly moves in, making its further use impossible without radical clearing and brush-removal. Much of the valley is divided into large ranches owned by local families whose history extends back into the 19 th century in the area.

As mentioned earlier in this report, comparatively little is known about existing archaeological sites in Goliad and Karnes Counties. Only one site has previously been recorded within the reservoir. This is an open campsite dating from Archaic to Neo-American times in Karnes County, which would be in the upper reaches of the reservoir. However, area residents have large collectlons of flint artifacts and tell of picking up numerous projectile points at local sites. No professional surveys have been done in the immediate area, but judging from the report of the Ecleto Creek survey done just north in Karnes County (Crawford 1971), the river valley should contain numerous open campsites and occasional workshop sites, some buried in alluvial terraces, and some on the surface of higher terraces, especial$1 y$ on low knolls near the river, near old river channels, or near the sites of the many never-falling springs which still fed the river in this area as late as the early 19th century, according to local informants. In cultivated areas, the old river channels axe difficult to discern but can stil1 be traced by the practiced eye. The sites will range in age from Paleo-Indian to Neo-American and many will include Historic period sites connected with the early 18 th century Spanish missions. The ranch headquarters of Rosario Mission is known to have been somewhere within the area and has not yet been located. 
Homes of early settlers and abandoned 19 th century town sites are scattered along the valley.

In early January 1975, an archaeological team from the Center for Archaeological Research, consisting of Anne For and Jules Jacquier, conducted a reconnaisance of the reservoir area, interviewing $10 c a 1$ residents and surveying a portion of the river valley to ascertain the general location and make-up of the sites. Several rumored prehistoric sites were noted, and one prehistoric and one historic site were recorded. The prehistoric site (41 GD 11) is an open campsite on a knoll overlooking Collier Lake, a stock tank built in an ald ox-bow lake west of the river just north of Golfad. Artifacts collected over a period of time from this site date it from Archaic into Neo-American times, and a few 19 th century artifacts present indicate a later occupation in the vicinity as we11.

The historic site ( $41 \mathrm{GD} 12$ ) is the town of Riverdale, which apparentiy reached its peak around the turn of the century and gradually declined until its abandonment in the early 19th century. Ruins are still visible within the overgrown river bend, and the Iron bridge which was once the center of the small community is still in use today.

In summary, the area to be covered by the Goliad Reservoir involves a large valley which has been intensively utilized by man from Paleomindian times to the present day. It is not an exaggeration to predict the presence of several hundred archaeological sites within the reservoir, about which virtually nothing is known at the present time. Intensive survey testing and selective excavation of these sites are urgently recommended as prelude to any future work on the reservoir. 
BIBLIOGRAPHY OF ARCHAEOLOGY IN THE STUDY AREA*

Listed on the following pages are published and unpublished studies resulting from archaeological research in the San Antonio-Guadalupe River Basins area. These references include both prehistoric and historic archaeological investigations. In several instances, unpublished references are listed as being on file at TARL (the Texas Archeological Research Laboratory at Balcones Research Center, The University of Texas at Austin). We are grateful to the personnel of TARL for their aid in the compilation of this bibliography.

\section{Bandera County}

Patterson, J. T:

Supplementaxy Notes on the Corner-tang Artifact. The University of Texas Bulletin 3734 27-39. 1937.

Patterson, L. W.

A Multiple Rock Midden Site. La Tierha 1 (3): 10-13. 1974.

Prismatic Blade Distribution in Tessas. La Tierra 1 (1):

9-14. 1974.

Reiter, Paul

In: Notes \& News: The Southwest. American Antiquity 13

(3): $272-273.1948$.

Suhm, Dee Ann, Alex D. Krieger, and Edward B. Jelks

An Introductory Handbook of Texas Archeology. Bulletin of the Texas Archeological Society 25. 1954.

Bexar County

Aveleyra Arroyo de Anda, Luis

The Second Mamoth and Associated Artifacts at Santa Isabel

Iztapan, Mexico. American Antiquity. 22 (1): 12-28. 1956.

E1 Segundo Mamut Fosil De Santa Isabel Iztapan Mexico, y Artefactos Asociados. Instituto Nacional de Ántropologia e Historia, Mexico D. F. 1955.

Campbe11, T. N:

Review: E. H. Sellards, Early man in America: A Study in Prehistory. Southwestern Historical quarterly (former1y The Quarterly of the Texas State Historical Association) 57 (1): 148-150. 1953.

Chadderdon, M. F. Notes on the Menger Collection, Site 41 BX 272, Bexar County, Texas. La Tierra 2 (1). 1975.

*Compiled by Lynn Highley and Thomas R. Hester 
Clark, J.W., Jr.

Preliminary Archeological Investigations at Wulff House, San Antonio, Texas. Texas Historical Commission, Special Reports, 14. 1974.

Collins, Michael $B$.

On the Peopling of Hitzfelder Cave. Bulletin of the Texas

Archeological Society 41: 201-304. 1970.

Dillehay, Tom D.

An Initial Archeological Reconnaissance of Areas to be Affected by the San Antonio Ranch New Town, Bexar County, Texas. Texas Archeological Salvage Project, Research Report 13. 1972.

Enlow, Donald H. and T. N. Campbell

Some Paleo-Indian Projectile Points from the Southeastern Periphery of the Great Plains. Panhandle-Plains Historical Review 28: 29-37. 1955.

Evans, Glen L.

The Friesenhahn Cave. Bulletin of the Texas Memorial Museum 2.

Fawcett, William B., Jr。

Prehistoric Site Models Based on Information from the Leon Creek Archaeological Survey, Bexar County, Texas. Archaeological. Papers Presented to $J$. W. House: 12-17. 1972.

A Prelininary Analysis of Prehistoric Utilization of Upland Areas Adjacent to Leon Creek, South Central Texas. La Tierra 1 (1): 27-31. 1974 .

Fox, Anne A. An Archeological Survey of the Northeast Preserve and J. Street Park. San Antonio, Texas. Submitted to State Antiquities Comittee (Manuscript on file at TARL). 1973.

(With an Appendix by Thomas $R_{\text {. Hester). An Archaeological }}$ Assessment of the Southern Portion of the Olmos Basin, Bexar County, Texas. The Center for Archaeological Research, The University of Texas at San Antonia, Anchaeological Survey Report 9. 1975.

Fox, Anne A., Feris A, Bass, Jr, and Thomas R. Hester The Archaeology and History of Alamo Plaza, Center for Archaeological Research. The University of Texas at San Antonio, Archaeological Survey Report 16. 1976.

Fox, Daniel E. Classen Ranch Site, Unpublished report, Witte Museum files, San Antonio. 1966.

Archaeological Salvage at Mission San Jose. December 1969, April and August 1970. On file Texas Historical Survey 
Comittee, Austin. 1970.

Fox, Daniel E, and Damon Kasper

The Classen Rockshelter Site. Unpublished report, Witte Museum files. San Antonio. 1967.

Givens, R. Dale

A Preliminary Report on Excavations at Hitzfelder Cave.

Bulletin of the Texas Archeological Society 28: 47-50. 1968.

Greer, John W.

A Description of the Stratigraphy, Features, and Artifacts from an Archeological Excavation at the Alamo. State Building Commision, Archeological Program, Report 3. 1967.

Hester, T. R. Archaeological Survey of Areas Proposed for Modification in the Salado Creek Watershed, Bexar County, Texas. Center for Archaeological Research. The University of Texas at San Antonio, Archaeological Survey Report 3. 1974.

Hester, T. R. and H. Kohnitz

The Chronological Placement of "Guadalupe" Tools. La Tierra 2 (2): $22-25$.

Howard, Calvin D. Paleo-Indian Surface Finds in Bexar County. La Tierra 1 (3): 14-17. 1974.

Hudson, William R., Jr., Warren M. Lynn, and Dan Scurlock Walker Ranch, an Archeological Reconnaissance and Excavations in Northern Bexar County, Texas. Texas Histarical Commission, ofjice of the State. Archeologist, Report 26. 1974.

Huesinger, Edward W.

Early Exploration and Mission Establishments in Texas. The Naylor Company, San Antonio. 1936.

Chronology of Events in San Antonio. Standard Printing Company, San Antonio, 1951.

Jackson, A. T.

The Fall Creek sites. University of Texas Publications 3802. 1938.

Pendants and Their Uses. Bulletin of the Texas Archeological and Paleontological Society 13: 9-15. 1941.

Picture-writing of Texas Indians. University of Texas Publication 3809. 1938. 
Ke1ley, J. Charles

Arrow or Dart Shaft Tool and Problematical Incised Stones

from Central and Western Texas. El Palacio 55 (3): 73-85. 1948.

Krieger, Alex D.

Anthropology at University of Texas. Boletin Bibliografico de Antropologia. Americana 14: 97-98. 1952.

In: Notes and News: Early Man. American Antiquity 16 (2): 182. 1950 .

New World Culture History: Anglo-America. In: A. L. Kroeber (editor) Anthropology Today: 238-264. University of Chicago

Press. Chicago 1953.

Martin, George C.

Texas Coastal Pottery. Bulletin of the Texas Archeological

and Paleontological Society 3: 53-56. 1931.

Mayer-Oakes, William J.

Relationship Between Plains Early Hunter and Eastern Archaic. Journal of the Washington Academy of Sciences 49 (5): 146156. 1959.

Orchard, C. D.

Two Etcetera Sites : Paper Presented at Texas Archeological

Society Annual Meeting, (Manuscript on file at TARL Library). 1966.

Orchard, C. D. and T. N. Campbel1

Evidences of Early Man from the Vicinity of San Antonio, Texas. The Texas Journal of Science 6 (4): 454-465. 1954.

Southwestern Pottery from Sites in the Vicinity of San Antonio, Texas. Texas Archeology 4 (2): 7-8. 1959.

Patterson, L.W. Prismatic Blade Distribution in Texas. La Tierra 1 (1): 9-14. 1974 .

A Quarry Site in Medina County, Texas. La Tierra 2 (1). 1975.

Pearce, J. E。

Need and Opportunities for Anthropological Research in the Southwest. The Southwestern Political and Social Science Quarterly 5 (3): 1-21. 1924.

Remsburg, George J。 (editor)

In: The Round Table. The Archaeological Bulletin 2 (4): 109. 1911. 
Roberts, Frank H. H., Jr.

Review: E. H. Sellards, Early Man in America: A Study in

Prehistory. American Antiquity 19 (2): 180-191. 1953.

Schuetz, Mardith $\mathrm{K}$.

Excavation of a Section of the Acequia Madre in Bexar County, Texas and Archeological Investigations at Mission San Jose in Apri1 1968. Texas Historical Survey Committee, Archeological Report 19. 1970.

The Granberg Site: An Archaic Indian Habitation in Bexar County, Texas. Witte Museum Studies. San Antonio. 1966.

Historic Background of the Mission San Antonio de Valero. State Building Commission, Archeological Program, Report 1. 1966.

The History and Archeology of Mission San Juan Capistrano, San Antonio, Texas. State Building Conmission, Archeological Program. Report 10 and 11.1968.

Scurlock, D. and $W$. R. Hudson, Jr.

An Archeological Investigation of Walker Ranch. Texas Historical Comission, Austin, 1973.

Sellards, E. H.

Early Man in America: A Study in Prehistory. University of

Texas Press. Austin. 1952.

Smith, Harvey $P ., J r o$ and Kenyon McDonald

An Archaeological Survey of Friedrich Park, Bexar County, Texas. Center for Archaeological Research. The University of Texas at San Antonio, Archaeological Survey Report, No. 12. 1975.

Sorrow, Willian M.

Archaeological Salvage Excavations at the Alamo (Mission San Antonio De Valero) 1970. Texas Archaeological Salvage Projects, Research Report 4. 1972.

Tunne11, Curtis

A Description of Enameled Earthenware from an Archeological Excavation at Mission San Antonio De Valero (The Alamo) 1966. State Building Commission, Archeological Program. Report 2. 1966.

Willey, Gordon R.

Method and Theory in American Archaeology. University of

Chicago Press. Chicago, 1958.

Woolford, Sam

Types of Archaeological Sites in Bexar County, Texas. Witte Memorial Museum Bulletin 4. 1935. 
Caldwel1 Councy

Baxter, E. P. and H. J. Shafer

Lower PIum Creek Watershed. Caldwe11, Texas. An Archeological Survey of Structures No. 38. Research Report, Anthropology Laboratory, Texas A and M University 3. 1974.

Patterson, J.T.

The Corner-tang Flint Artifacts of Texas. University of Texas Bulletin 3802. 1936.

Scarborough, Joetta

Excavation of a Burlal at the Cochran site: 41CW3. The BullRoarer, Newsletter of the University of Texas Anthropological

Society 3 (I) 1968 .

Walker, Jimmy

The First Texan, Texas Parade 16(9): 24-27, 1956.

Watt, Frank $\mathrm{H}$.

Lookout Point. Central Texas Archaeologist 8: 27-39.

Wesolowslky, A. B. and T. S. Ellzey

The Human Skeleton from the Cochran site: 41cw3. The BullRoarer Newsletter of the University of Texas Anthropological Society 3 (1) 1968.

Calhoun County

Bass, F. A., Jr。

Assessment of Archaeological Resources in Portions of the Chocolate Creek, Little Chocolate Creek and Lynns Bayou Watershed, Victoria and Calhoun Counties, Texas. Center for Archaeological Research, The University of Texas at San Antonio Archaeological Survey Report 2. 1974.

Briggs, Alton $\mathrm{K}$.

Archeological Resources in the Texas Lowlands and Littoral. Texas Historical Survey Committee and Texas Water Development Board 1971.

Comstock, Douglas B., Kerry A. Grombacker, and David S. Dibble A Study of the Effects of She11 Dredging on the Archeological and Historical Resources of San Antonio Bay, Texas. Texas Archeological Survey, Research Report 23. 1973.

Fritz, Gayle

Filot Archeological Field Survey of Cox Bay, Calhoun County, Texas. Matagorda Bay - Estuarine Resource Management Study. Envirommental Planning Division of Texas General Land office. 1972 .

Gilnore, Kathleen

The Keeran Site: The Probable Site of La Salle's Fort st. Louis in Texas. Texas Historical Comission. Office of the State Archeologist Reponts 24. 1973. 
Kennard, Don

Matagorda Island: A Natural Area Survey (Part II of IV). Lyndon B. Johnson School of Public Afrairs, The University of Texas at Austin. 1973.

Martin, George C. Texas Coastal Pottery. Bulletin of the Texas Ancheological and Paleontological Society 3: 53-56. 1931.

Poteet, Sybil

The Occurrence and Distribution of Beveled Knives. Bulletin of the Texas Archeological and Paleontological Society 10: 245-262. 1938.

Potter, Wende11 $\mathrm{H}$.

Ornamentation on the Pottery of the Texas Coastal Tribes. Bulletin of the Texas Archeological and Paleontological Society. 2: 41-44. 1930.

Suhn, Dee Ann, Alex D. Krieger, and Edward B. Jelks An Introductory Handbook to Texas Archeology. Bulletin of the Texas Archeological Society 25. 1954.

Udden, J. A.

The Origin of the Sma11 Sand Mounds of the Gulf Coast Country. Science 23 (598) 849-851. 1906.

Wingate, R. Fo and Thomas Roy Hester

Ten Burials from Green Lake, Texas. Florida Anthropologist 25 (3): 119-127, 1972 .

\section{Coma1 County}

Alexander, Herbert

An Analysis of the Stone Flakes from the Oblate Site, Canyon Reservoir. (On file at TARL). M.d.

Anonymous (Robert E. Bel1)

News - Meeting of the Texas Archaeological Society. Oklahoma Anthropological Saciety Newsletier 8 (4): 3-7. 1959.

Collins, Michael $\mathrm{B}$. The oblate Site, 41CMI, Comal County, Texas: 1963 Excavations (Unpublished report in 1966)

Hester, Thomas R., Feris A. Bass, Jr. and Thomas C. Kelly Archaeological Survey of Portions of the Comal River Watershed, Coma1 County, Texas. The Center for Archaeological Research, The University of Texas at San Antonio Archaeological Survey Report, No. 6. January 5, 1975.

Jackson, A. T.

The Fall creek sites. Universty of Texas Publication 3802. 1938. 
Pendants and Their Uses. Bulletin of the Texas Archeological and Paleontological society 13: 9-15. 1941.

Tubular Pipes and Other Tubes in Texas. Bulletin of the Texas Archeological and Paleontological Society. 12: 99-137. 1940.

Johnson, LeRoy, Jr., Dee Ann Suhm, and Curtis 0. Tunnel1

Salvage Archeology of Canyon Reservoir: The Wunderlich, Footbridge and oblate sites. Texas Memorial Museum Bulletin 5. 1962.

Kelley, Charles J.

Arrow or Dart Shaft Tools and Problenatical Incised Stones Erom Central and Western Texas. El Palacio 55 (3): 73-85. 1948.

Kelly, Thomas $C$. and Thomas $R$. Hester

Additional Archaeological Survey in the Dry Comal Watershed, Comal County, South Central Texas. Center fort Archaeological Research, The University of Texas at San Antonio Archaeological Survey Report, No. 10. 1975.

Archaeologlcal Investigations at Four Sites in the Dry Comal Watershed Comal County, South Central Texas. Center for Archaeological Research, The University of Texas at San Antonio Archaeological Survey Report, No. 15. 1975.

New, Ina Claire

The Race Against Water by University of Texas Archaeologists.

The Alcalde 48 (1): 12-15. 1959.

Patterson, J.T.

Boat-shaped Artifacts of the Gulf Southwest States. University of Texas Bulletin 3732. 1937.

The Comer-tang Flint Artifacts of Texas. Univensty of Texas Bulletin 3618. 1936.

Patterson, L. W.

Prismatic Blade Distribution in Texas. La Tierra I (1): 9-14. 1974.

Shafer, Harry $J$. Archeological Survey of the Blieder's Creek Reservoir. Manuscript on file: Texas Archeological Survey, Austin, n.d.

Stephenson, Robert L.

Archaeological Survey of Canyon Reservoir on the Guadalupe River, Comal County, Texas. On file, Smithsonian Institution; River Basins Survey, Lincoln, Nebraska. 1949.

A Preliminary Survey of Canyon Reservoir, Comal County, Texas. Mimeographed Report of the River Basin Surveys, Smithsonian

Institution, Austin Office. 1951. 
River Basin Surveys in Texas. Plains Archaeological Conference News Lexter 2 (4): 8-9. 1949.

Wilson, Thomas

Arrowpoints, Spearheads, and Knives of Prehistoric Times. Report of the United States National Museum 1897: 811-988. 1899.

\section{DeWitt County}

Briggs, Alton $\mathrm{K}$. Archeological Resources in the Texas Coastal Lowlands and Littoral. Texas Historical Survey Commitiee and Texas water Development Boand. 1971.

Crawford, Daymond D.

An Archeological Reconnaissance of Ecleto Creek Watershed South Central Texas. Texas Archeological Salvage Project Survey Report 8. 1971.

Fox, Daniel E., Robert J. Mallouf, Nancy Q'Malley and William M. Sorrow Proposed Cuero I Reservoir. Texas Historical Comission and Texas Water Development Board, Archeological Survey Report 12. 1974.

Patterson, J. T. The Comer-tang Elint Artifacts of Texas. The University of Teras Bulletin 3618.1936.

Pearce, J. E. The Urgent Need for a Texas State Museum. Texas Museum Association Bulletin. n.d.

Suhm, Dee Ann, Alest D. Krieger, and Edward B. Jelks An Introductory Handbook of Texas Archaeology. Bulletin of the Texas Archeological Society 25. 1954.

\section{Goliad County}

Briggs, Alton $\mathrm{K}$.

Archeological Resources in the Texas Coastal Lowlands and Littoral. Texas Historical Si zuey Committee and Texas water Development Boand. 1971.

Goldstein, Marcus Skeletal Pathology of Early Indians in Texas. American Journal of Physical Anthropology 15 (3): 299-312. 1957.

Gross, Hugo Mastodons, Mammoths, and Man in America. Bulletin of the Texas Archeological and Paleontological Society 22: 101-131. 1951.

Hester, Thomas Roy and Robert C. Parker The Berclair Site: A Late Prehistoric Component in Goliad County, Southern Texas. Bulletin of the Texas Archeological 
Society 41: 1-24. 1970.

Jackson, A.T.

Ornaments of East Texas Indians. Bulletin of the Texas Archeological and Paleontological Society 7: 11-28. 1935.

Types of East Texas Pottery. Bulletin of the Texas Archeological and Paleontological Society. 6: 38-57. 1934.

Krieger, Alex D.

Culture Complexes and Chronology in Northern Texas. University of Texas Publications 4640. 1946 .

Patterson, L.W.

Prismatic Blade Distribution in Texas. La Tierra 1 (1) 9-14. 1974.

Reed, Erik $K_{\text {o }}$

Burlals at Mission Espiritu Santo. The Central Texas Archaeologist 4: $85-95.1938$.

In: Notes and News: Southwestern Area. American Antiquity 6 (3). 283. 1941.

Revised Goliad State Park Master Plan Report. United States Department of the Interior, National Park Service, and Goliad State Park Commission.

Sellards, E. H.

Early Man in America: Index to Localities and Selected Bibliography, 1940-1945. Bulletin of the Geological Society of America 58: 955-978. 1947.

Pleistocene Artifacts and Assoclated Fossils from Bee County. Bulletin of the Geological Society of America 51: 1627-1657. 1940 .

Wi1son, Thomas

Arrowheads, Spearheads, and Knives of Prehistoric Times. Report of the United States National Museum 1897: 811-988. 1899.

Wright, Welty

The Type, Distribution, and Occurrence of Flint Gravers in Texas. Bulletin of the Texas Archeological and Paleontological Saciety 12: 31-48. 1940.

$$
\text { Gonzales County }
$$

Crawford, Daymond D.

An Archeological Reconnaissance of Ecleto Creek Watershed South Central Texas. Texas Archeological Salvage Project Sunvely Report 8. 1971. 
Fox, Daniel E., Robert J. Mallouf, Nancy O'Malley, and W1lliam M. Sorrow Proposed Cuero I Reservoir. Texas Historical Commission and Texas water Development Board, Archeological Survey Report 12. 1974.

Orchard, C. D.

Letter on Fort Wahl. On flle, University of Texas at San Antonio Center for Archaeologica1 Research. 1974.

\section{Guadalupe County}

Patterson, J.T.

Boat-shaped Artifacts of the Gulf Southwest States. University of Texas Bulletin 3732. 1937.

The Comer-tang Flint Artifacts of Texas. The University of Texas Bulletin 3618. 1936.

Supplementary Notes on the Corner-Tang Artifact. The University of Texas Bulletin 3734: 27-39. 1937.

Hays County

Hough, Walter

A New Type of Stone Knife. American Anthropologist 29 (2): 296-298. 1927.

Patterson, J.T.

The Corner-tang Flint Artifacts of Texas. The University of Texas Bulletin 3618. 1936.

Patterson, Patience E.

Upper San Marcos River Watershed, Hays County, Texas: An Archeological Survey of Areas Proposed for Modification. Texas Archeological Survey, Research Report 42. 1974.

Pearce, J.E. In: Archaeological Work by State Agencies in 1925. American Anthropologist 28 (4): 690-694. 1926.

Need and Opportunities for Anthropological Research in the Southwest. The Southwestern Political and Social Science quarterly 5 (3): 1-21. 1924.

Poteet, Sybil

The Occurrence and Distribution of Beveled Knives. Bulletin of the Texas Archeological and Paleontological Society 10: 245-262. 1938.

Roberson; Wayne

The Study of Extinct Rural Communities in the United States. A Test of Feasibility. M.A. Thesis, University of Texas at Austin, 1972.

Smith, H. Po, Jr。 Dig That Square: A Lesson from Timmeron Rockshelter. La Tierra 2 (2). 1975 . 


\section{Karnes County}

Birmingham, W. W., E. H. Schmiedlin, and T. R. Hester A Note on Paleo-Indian Artifacts from a Site in Karnes County, Texas. Newsletter, Houston Anchaeological Society. 42:3-8. 1972.

Calhoun, C. A.

A Sma11 Campsite Near Kenedy, Texas. Newsletter, Houston Archaeological Society. 18:3-6. 1966.

Crawford, Daymond D.

An Archaeological Recomnaissance of Ecleto Creek Watershed South Central Texas. Texas Archeological Salvage Project Survey Report 8. 1971.

Fox, Anne

An Archaeological Survey of the Nichols Creek Channel Modification, Karnes County, Texas. Center for Archaeological Research. The University of Texas at San Antonio, Archaeological Survey Report 5. 1974.

Patterson, J. T.

Supplementary Notes on the Corner-tang Artifact. University of

Texas Bulletin 3734: 27-39. 1937.

\section{Kenda11 County}

Bass, Feris A., Jr, and Thomas R. Hester

An Archaeological Survey of the Upper Cibolo Creek Watershed, Central Texas. Center for Archaeological Research, The University of Texas at San Antonio Archaeological Survey Report No. 8. 1975.

Enlow, Donald H. and T. N. Campbell

Some Paleo-Indian Projectile Points from the Southeastern Periphery of the Great Plains. Panhandle-Plains Historical Review

$28: 29-37.1955$.

Patterson, J, T.

The Corner-tang Flint Artifacts of Texas. The University of Texas Bulletin 3618. 1936.

Wentworth, Irving $\mathrm{H}$.

A Few Notes on Indian Mounds in Texas. Science 23 (595) 818-819.

Kerr County

Briggs, Alton $\mathrm{K}$.

An Archeological Survey of Ingram Reservoir. Texas Histarical Survey Committee and Texas Water Development Board, Archeological Survey Report 9. 1971. 
Goldschmidt, Walter R.

Reconnaissance in Kerr County. Manuscript on file, Texas

Archeological Research Laboratory. Austin, 1934.

Jackson, A. T.

Pendants and Their Uses. Bulletin of the Texas Archeological

and Paleontological Society 13: 9-15. 1941.

Picture-writing of Texas Indians. University of Texas

Publication 3809. 1938.

Patterson, J.T.

Boat-shaped Artifacts of the Gulf Southwest States. University

of Texas Bulletin 3732. 1937.

The Corner-tang Fint Artifacts of Texas. The University of

Texas Bulletin 3618. 1936.

Poteet, Sybil

The Occurrence and Distributions of Beveled Knives. Bulletin of

the Texas Archeological and Paleontological Society. 10:245-262. 1938.

Skinner, S. A.

Prehistoric Settlement of a Natural Area. Ph.D. dissertation, Southern Methodist University. 1974.

Sollberger, J. B.

Lamb's Creek Mound. The Record 7 (1): 2-5. 1948.

A Prehistoric Rock Shelter in Kerr County, Texas. The Record

$8(3): 9-14.1949$.

Sollberger, J. B. and Thomas R. Hester

The Strohacker Site: A Review of PremArchaic Manifestations in

Texas. Plains Anthropologist. 1972.

Medina County

Patterson, J. T.

Supplementary Notes on the Corner-tang Artifact. University

of Texas Bullexin 3754: 27-39. 1937.

Patterson, L. W.

Prismatic Blade Distribution in Texas. La Tierra 1 (1): 9-14. 1974.

Uvalde County

Anonymous

Field Work of Members. Bulletin of the Texas Archeological and

Paleontological Society 3: 90m94. 1931. 
Arguedas, R. de la Borbolla, Sol, and Luis Aveleyra Arroyo de Anda. A Plainview Point from Northern Tamaulipas. American Antiquity $18(4): 392-393.1953$.

Bel1, Robert H. Guide to the Identification of Certain Types of American Indian Projectile Points. Special Bulletin of the Oklahoma Anthropological Society 1. 1958.

Campbe11, T. N.

Review: E. H. Sellards, Early Man in America: A Study in Prehistory. Southwestern Historical Quarterly 57 (1): 148-150. 1953.

Elrod, Henry E.

Fint: Its Occurrence, Composition, and Patina. Bulletin of the Texas Archeological and Paleontological Society 5: 53-56. 1933.

Ha11, Grant D.

Leona River Watershed, Uvalde County, Texas: An Archaeological and Historical Survey of Areas Proposed for Modification. Texas Archeological Survey Research Report. 37. 1974.

Hester, Thomas Roy

Burned Rock Middens on the Southwestern Edge of the Edwards Plateau, Texas. Plains Anthropologist 15 (50): 237-250. 1970.

Archeological Investigations at the La Jita Site, Uvalde County, Texas. Bulletin of the Texas Archeological Society

42: $51-148.1971$.

Notes on the She1I Remains from the La Jita Site. Bulletin of the Texas Archeological Society 42: 144-146. 1971.

Other Sites in the Vicinty of the La Jita Site. Bulletin of the Texas Archeological Society 42: 146-148. 1971.

Hi11, T. C., Jr., and Thomas R. Hester

A Plainview Point from a Stratified Site on the Southwestern Edge of the Edwards Plateau, Texas. Texas Archeology 16 (3): 14-17. 1972 .

Huskey, Vane

An Archeological Survey of the Nueces Canyon of Texas. Bulletin of the Texas Archeological and Paleontological Society 7: 105-114. 1935.

Jackson, A. T.

The Fall Creek Sites. The University of Texas Publication 3802:

11-118. 1938 . 
Pendants and Their Uses. Bulletin of the Texas Archeological and Paleontological Society 13:9-45. 1941.

Picture-writing of Texas Indians. The University of Texas

Publication 3809. 1938.

Johnson, Frederick

Archaeological News: American Archaeology, 1948. American

Journal of Archaeology 53 (3): 286-301. 1949.

Kelley, J。Charles

Arrow or Dart Shaft Tools and Problematical Incised Stones from

Central and Western Texas. El Palacio 55(3): 73-85. 1948.

Libby, W. F.

Chicago Radiocarbon Dates, I-III. Science 116 (3025): 673-681. 1952.

Mear, Charles

Folsom Culture. Man 1 (2): 15, 39-40. 1948.

Morrow, James $G$.

A Prehistoric Cremated Burial of the Abilene Region. Bulletin of the Texas Archeological and Paleontological Society 8: 17-24. 1936 .

Orchard, C. D. and T. N. Campbe11

Evidences of Early Man from the Vicinity of San Antonio, Texas.

Texas Journal of Science 6 (4): 454-465. 1954.

Patterson, J.T.

The Corner-tang Flint Artifacts of Texas. The liniversity of

Texas Bulletin 3618. 1936.

Patterson, L. W.

Prismatic Blade Distribution in Texas. La Tierra 1 (1): 9-14. 1974.

Poteet, Sybil

The Occurrence and Distributions of Beveled Knives. Bulletin of the Texas Archeological and Paleontological Society 10:245-262. 1938.

Roberts, Frank H. H.

Review: E. H. Sellards, Early Man in America: A Study in Prehistory. Amenican Antiquity 19(2): 180-191. 1953.

Sellards, E. H.

Early man in America: A Study in Prehistory. University of Texas

Press, Austin, 1952.

Suhm, Dee Ann

Excavations at the Collins Site, Travis County, Texas. Bulletin of the Texas Archeological Society 26:7-54. 1956. 
Suhm, Dee Ann, Alex D. Krieger and Edward B. Jelks An Introductory Handbook to Texas Archaeology. Bulletin of the Texas Archeological Society 25. 1954.

Wedel, Waldo R.

In: Notes and News. American Antiquity 14 (1): 74-75. 1948.

In: Notes and News. American Antiquity 14 (3): 2-4-245. 1949.

White, Patrick J.

Caves of Central Texas. In: The Caves of Texas. Bulletin of the National Speleological Society 10: 46-48. 1937.

Victoria County

Arguedas R. de la Borbolla, Sol, and Luis Arroyo de Anda A Plainview Point from Northern Tamaulipas. American Antiquity 18 (4): 392-393. 1953.

Be11, Robert E.

Guide to the Identification of Certain American Indian Projectile Points. Special Bulletin of the Oklahoma Anthropological Society 1. 1958 .

Birmingham, W. W. and T. R. Hester

(in press) Postulated Early Occupation at the Johnston Site, Texas Coastal Plain. Texas Journal of Science (to appear in 1975).

Briggs, Alton $\mathrm{K}$.

Archeological Resources in the Texas Coastal Lowlands and Littoral. Texas Historical Survey Committee and Texas water Development Board. 1971.

Campbe11, T. N。

Excavations at the Morhiss Site, Victoria County, By the University of Texas, 1938-40. Paper presented at the Annual Meeting of the Texas Archeological Society, Victoria, 1962.

Dorsey, H. W.

In: Archaeological Field Work in North America during 1931. American Ánthropologist 34(3): 503. 1932.

Duffen, William A. Morhiss Site. Texas Archaeological News 2:16-18. 1940.

Gilmore, Kathleen

The Keeran Site, The Probable Site of La Salle's Ft. St. Louis, in Texas. Texas Historical Commission, office of the State Archeologisit Reports, 24. 1973. 
Goldstein, Marcus S.

Skeletal Pathology of Early Indians in Texas. American Journal of Physical Anthropology 6 (1): 63-84. 1948.

Some Notes on Texas Crania (abstract). American Journal of Physical Anthropology 27(3): 16. 1940.

Hrdlicka, Ales

Catalog of Human Crania in the United States National Museum Collections: Indians of the Gulf States. Proceedings of the United States National Museum 87 (3076): 315-464. 1940.

Jackson, A. T.

Ornaments of East Texas Indians. Bulletin of the Texas Archeological and Paleontological Society 7: 11-28. 1935.

Pendants and Their Uses. Bulletin of the Texas Archeological and Paleontological Society 13: 9-45. 1941.

Krieger, Alex D.

Some Suggestions on Archeological Terms. Bulletin of the Texas

Archeological and Paleontological Society 16: 41-51. 1945.

MacNeish, Richard S,

Preliminary Archaeological Investigations in the Sierra de Tamaulipas, Mexico. Transactions of the American Philosophical Society 48 (6): 1958.

Orchard, C. D. and T. N. Campbe1l

Evidences of Early Man from the Vicinity of San Antonio, Texas.

Texas Journal of Science $6(4): 454-465$. 1954.

Pearce, J. E.

The Present Status of Texas Archeology. Bulletin of the Texas

Archeological and Paleontological Society 4: 44-54. 1932.

The Urgent Need for a Texas State Museum. Texas Museum Association Bulletin. n.d.

Potter, Wende11 H.

Ornamentation on the Pottery of the Texas Coastal Tribes. Bulletin

of the Texas Archeological and Paleontological Society 2: 41-44.

Reed, Erik K.

In: Notes and News: Historic Sites. American Antiquity 17 (1):

79. 1951.

Sellards, E. H.

Pleistocene Artifacts and Assoclated Fossils from Bee County, Texas. Bulletin of the Geological Society of America 51: 1627-1657. 1940. 
Setzler, Frank M.

A Prehistoric Cave in Texas. Explorations and Fieldwork of the Smithsonian Institution, 1931: 133-140. 1932.

Suhm, Dee Ann, Alex D. Krieger and Edward B. Jelks An Introductory Handbook of Texas Archeology. Bulletin of the Texas Archeological Society 25. 1954.

Watt, Frank H.

The Waco Sinker. Central Texas Archaeologist 4: 21-70. 1938.

Wright, WeIty

The Type, Distribution, and Occurrence of F1int Gravers in Texas. Bulletin of the Texas Archeological and Paleontological Society 12: 31-48. 1940 .

\section{Wilson County}

Crawford, Daymond D.

An Archeological Reconnaissance of Ecleto Creek Watershed, South Centra1 Texas. Texas Archeological Salvage Project, Survey Reports 8. 1971.

Hsu, Dick Ping and Ronald W. Ralph An Appraisal of the Archeological Resources of Cibolo Reservoir, Wilson County, Texas. Archeological Survey Report No. 1, Texas State Building Commission and Texas State Water Development Board. 1968.

Jackson, Joe L.

Cibolo Dam and Reservoir Site: Preliminary Geological Report. U. S. Department of the Interion, Bureau of Reclamation, Austin. n.d.

Patterson, J. T. The Corner-tang Flint Artifacts of Texas. The University of Texas Bulletin 3618. 1936. 
A GENERAL OVERVIEW OF INDIAN CULTURES*

The Indian occupations of the study area can be divided into two distinct areas: those groups who occupied the central portion of the state, and those occupying the counties which lie along the coastal plain in the area south of a line between Del RIo and Galveston.

The central Texas area was the home, in early historic times, of the Tonkawa Indlans (Newcomb 1961). How early they arrived is not known, but it is thought that they may be linked to the late prehistoric sites in the area (Suhm 1958).

The Tonkawa (and their late prehistoric predecessors) were a hunting and gathering society, engaged in some fishing, and possibly, horticulture. The occupation sites were concentrated along the streams and rivers of central Texas. They seem to have of ten camped on or near the burned rock middens of the earlier Archaic peoples. The Tonkawa manufactured some plain pottery and apparently obtained some in trade from the tribes of eastern Texas.

The Tonkawa, it is believed, probably depended heavily on the bison for food and clothing during the earlier phase of their existence, but, due to encroachment by the Comanche and other plains tribes, were later forced to depend upon smaller game, including deer and small animals such as skuniks, rabbits, and rats.

Housing for the Tonkawa was usually a small, squat, crude structure supported by a tripod of branches covered with grass, branches, and brush. In later years cloth and hides sometimes replaced this vegetative cover.

Their main weapon was the bow and arrow, stoned-tipped at first, but with metal points substituted as that material became available from the Europeans. The juice of the mistletoe was used, mistakenly, to poison their arrows, a belief that persisted during their use of the gun when the juice was poured down the gun barrel.

The Tonkawa were jolned by the Lipan Apache at about the middle of the 19 th century, the latter having been pushed into the area by the aggressive Comanches. There is little or no material evidence remaining of this Apache occupation due largely to the semi-nomadic life-style of these peoples. However, 19th century accounts provide some clues to their mode of life. By the time of their arrival in Central Texas they had become hunters of bison, deer, and antelope, a pursuit in which the horse was employed, as the Iipan Apache were accomplished horsemen. Their primary weapon was the bow and arrow.

The meat diet derived from hunting was supplemented by wild plant food. The various species of agave were a mainstay of this portion of their diet as well as providing raw materials from which they made various

*Compiled by Feris A. Bass, Jr. 
articles of clothing and equipment.

Lipan Apache housing was the more conventional tipi composed of light poles over which bison hides were thrown. Some were large enough to accommodate a dozen people; others were smaller, housing only three or four.

Oppressed by their enemies, the Comanche, the Spaniard, and the Anglo-American settler, the Lipan Apache became the riffraff of the Texas frontier.

By the time the Anglo-American entered Texas, the Comanches were the dominant Indian Group in our area of study, ranging and raiding throughout the state.

As a typical Plains Indian group, the resources provided by buffalo were the mainstays of Comanche material culture. The weapons employed in hunting bison were the bow and arrow and the lance. The hunt was usually a communal affair in which an attempt, usually successful, was made to surround a herd causing it to mill about for an easier ki11. Occasionally herds were driven off cliffs. Butchering took place after the $\mathrm{kill}$, and the meat was transported back to camp. Longhorn cattle occasionally replaced the buffalo as a meat source.

The Comanche diet also included wild plants and fruits such as plums, grapes, juniper berries, persimmons, fruits of the prickly pears, etc. Pemican was also made and eaten.

Their housing was the usual plains-type tipi made of tanned buffalo hides and light poles. These structures usually stood about 14 to 18 feet high.

The Comanche way of life was almost completely centered around warfare and during most of their recorded history, they were engaged in such pursuit. Every male Comanche was a warrior comitted to fight as a means of achieving social status. Their warlike nature was a factor in their long resistance, lasting until 1875, to AngloAmerican expansion into northern and western Texas.

The major Indian groups in the southern and coastal region of the study area were the Coahuiltecans and Karankawas, the latter being found along the central Texas coast. One of the multitude of Coahuiltecan groups was the Payayas, 1iving in the vicinity of present day San Antonio. Other groups were present in the area between the San Antonio and Guadalupe Rivers.

The early history of the Coahuiltecans is quite obscure and little is known of their origin. But avallable evidence would indicate that they had existed in the area as a rather static society over a very long period, from at least Archaic times until the beginning of the 19th century. 
The culture of the Coahuiltecans was quite primitive, perhaps dictated by the severity of the terrain in which they lived. Their dependence upon plant and aninal resources for their support necessitated a seminomadic form of life. Reports from early Spanish explorers indicate that nothing edible was shunned as food - including many items not considered palatable by modern society. Plant foods were probably the principal item in their subsistance regime. The prickly pear tuna was an important staple, as were the mesquite bean and the agave.

The principal weapon of the Coahuiltecans was the bow and arrow. The bow was often made from mesquite roots and the arrow from cane with hardwood foreshafts tipped with flint points. Another "weapon" was the curved, wooden "rabbit stick," which was used for digging, grubbing, prying, and throwing. Knives, scrapers, and hammers were made of flint.

The housing of the Coahuiltecan was usually made by bending over saplings on which were placed reed mats and hides forming low, circular huts. The camps of the Coahuiltecan were, according to the Spaniards, rather filthy, with refuse piled about indiscriminately.

The Karankawa peoples are known from the Central Texas coast, and were probably present in the eastern portions of the study area. How long they and their ancestors had occupied the coastal area is unknown, but it appears that such had been the case since at least Archaic times.

As might be expected, the Karankawa utilized most of the coastal marine resources, both as food items and as a source for raw material for tool manufacture. On the mainland, deer, bison, bear, alligator, and other animals were utilized.

The Karankawa lived a highly mobile maritime existence facilitated by the use of dugout canoes made from hollowed-out tree trunks. Their housing was portable; made of willow poles 18 feet long which were set into the ground in a circle, the upper ends tied together and covered with skins and woven mats. These were usually about 10 feet in diameter. Pottery-making was practiced, resulting in a distinctive pottery often decorated with asphaltum bands on the exterfor and coated with asphaltum on the interior.

Their chief weapon was the bow and arrow, with the arrow points attached with asphaltum. Other weapons used were the lance and clubs.

The Karankawas were often accused of cannibalism, but in fact this was little more than a ritual practice, also followed by many other North American Indian groups.

In the following pages, we have listed selected references dealing with historic Indian peoples in the study area. The bibliographies 
contained in many of these publications contain further sources relating to the region's Indian cultures.

\section{BIBLIOGRAPHY}

Berlandier, Jean Louis

1969 The Indians of Texas in 1830. J. Ewers, ed. Smithsonian Institution Press.

Bolton, Herbert Eugene

1962 Texas in the Middle Eighteenth Century. Russel1 and Russe11, New York.

Campbe11, T. N. 1975

The Payaya Indians of Southern Texas. Southern Texas Archaeological Association. Special Publication No. 1.

Day, James M. et al 1971 Indian Tribes of Texas. Texan Press, Waco.

Dennis, T. S. and Mrs. T. D. Dennis

1925 Libe of F. M. Buckelew, The Indian Captive, as Related by Himself. Bandera, Teras.

Gatschet, A. A.

1891 The Karankawa Indians, the Coast People of Texas. Archeological and Ethnological Papers of the Peabody Museum, 1(2).

Hodge, F. W. (editor)

1907 The Narrative of Alvar Nunez Cabeza de Vaca. In:

Spanish Explorers in the Southern united States,

1528-1543. New York.

Hoijer, Harry

1949

Analytical Dictionary of the Tonkawa Language. University of California Publications in Linguistics 5: 1-74.

1952 Tonkawa Indians. In: Walter P. Webb (editor), The Handbook of Texas. 2: 788-789.

Hunter, J. Marum

1931 The Bloody Trail in Texas. Privately published, Kerrville, Texas.

Krieger, A. D.

1956 Food Habits of the Texas Coastal Indians in the Early Sixteenth Century. Bulletin of the Texas Archeological Society 27: $45-58$.

McCracken, Harold

1959 George Catlin and the old Frontier. Bonanza Books, New York. 
Martin, George C.

1936 The Indian Tribes of the Mission Nuestra Senora del Refugio. San Antonio.

1972 Indians of the Mission Nuestra Señona del Refugio. Bootstraps Press, Corpus Christi.

Newcomb, W. W. Jr.

1956 A Reappraisal of the "Cultural Sink" of Texas. Southwestern. Journal of Anthropology 12 (2): 145-153.

1960 The Indian Tribes of Texas. Bulletin of the Texas Archeological Society 29: 1-34.

1961 The Indians of Texas. University of Teras Press, Austin.

Nunley, J.P.

1971 Archeological Interpretation and the Particularistic Model: The Coahuiltecan Case. Plains Anthropologist $16(54): 302-310$.

Opler, M. E.

1940 Myths and Legends of the Lipan Apache Indians. Memoirs of the American Folklore Society. 36: 1-296.

Ruecking, Frederick, Jr.

1953 The Economic System of the Coahuiltecan Indians of Southern Texas and Northeastern Mexico. Texas Journal of Science 5 (4): 470-489.

1954 Ceremonies of the Coahuiltecan Indians of Southern Texas and Northeastem Mexico. Texas Journal of Science 6 (3): $330-339$.

1955 The Social Organization of the Coahuiltecan Indians of Southern Texas and Northeastern Mexico. Texas Journal of Science 7 (4): $357-388$.

Schaede1, Richard P.

1949 The Karankawa of the Texas Gulf Coast. Southwestern Journal of Anthropology 5 (2): 117-137.

Scurlock, D. et al

1974 An Assessment of the Archeological Resources of Padre Island National Seashore, Texas. Texas Historical Commission, office of the State Archeologist Special Reports 11 .

Sjoberg, Andrée F.

1953 The Culture of the Tonkawa, A Tezas Indian Tribe. Texas Journal of Science 5 (3): 280-304. 
Skee1s, Lydia L. M.

1972 An Ethnohistorical Survey of Texas Indians. Texas

Historical Survey Committee Archeological Reports 22.

Suhm, Dee Ann

1958

A Review of Central Texas Archeology. Bulletin of the Texas Archeological Society 29: 63-108.

Swanton, John R.

1911 Indian Tribes of the Lower Mississippi Valley and Adjacent Coast of the Gulf of Mexico. Bureau of. American

Ethnology. Bulletin 43.

1915 Linguistic Position of the Tribes of Southern Texas and Northeastern Mexico. American Anthropologist 17(1): $17-40$.

1940 Linguistic Material from the Tribes of Southern Texas and Northeastern Mexico. Bureau of American. Ethnology, Bulletin 127.

Troike, Rudolph $C_{\text {. }}$

1961 Researches in Coahuiltecan Ethnography. Bulletin of the Texas Archeological Society 30: 301-309.

1962 Notes on Coahuiltecan Ethnography. Bulletin of the Texas Archeological Society 32: 57-63.

Wallace, Ernest and E. A. Hoebel

1952 The comanches, Lords of the South Plains. University of Oklahoma Press, Norman.

Wood, Alpha Kennedy

1971 Texas Coastal Bend: People and Places. Naylor,

San Antonio.

Yoakum, Henderson

1855 History of Texas. Redfield, New York. 


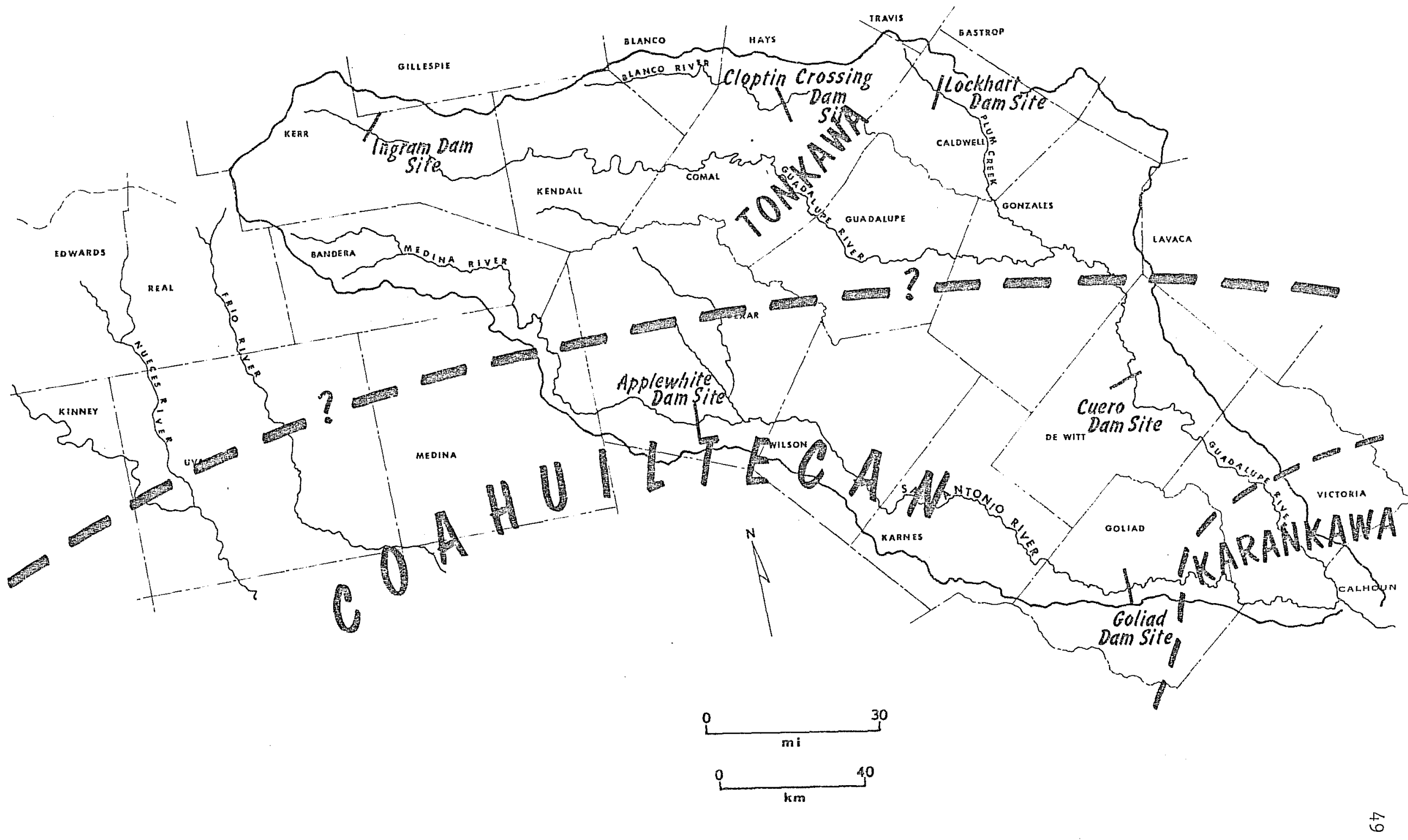

Figure 3. Approximate Locations of Major Indian Groups in the Study Area During the Sixteenth and Seventeenth Centuries. 


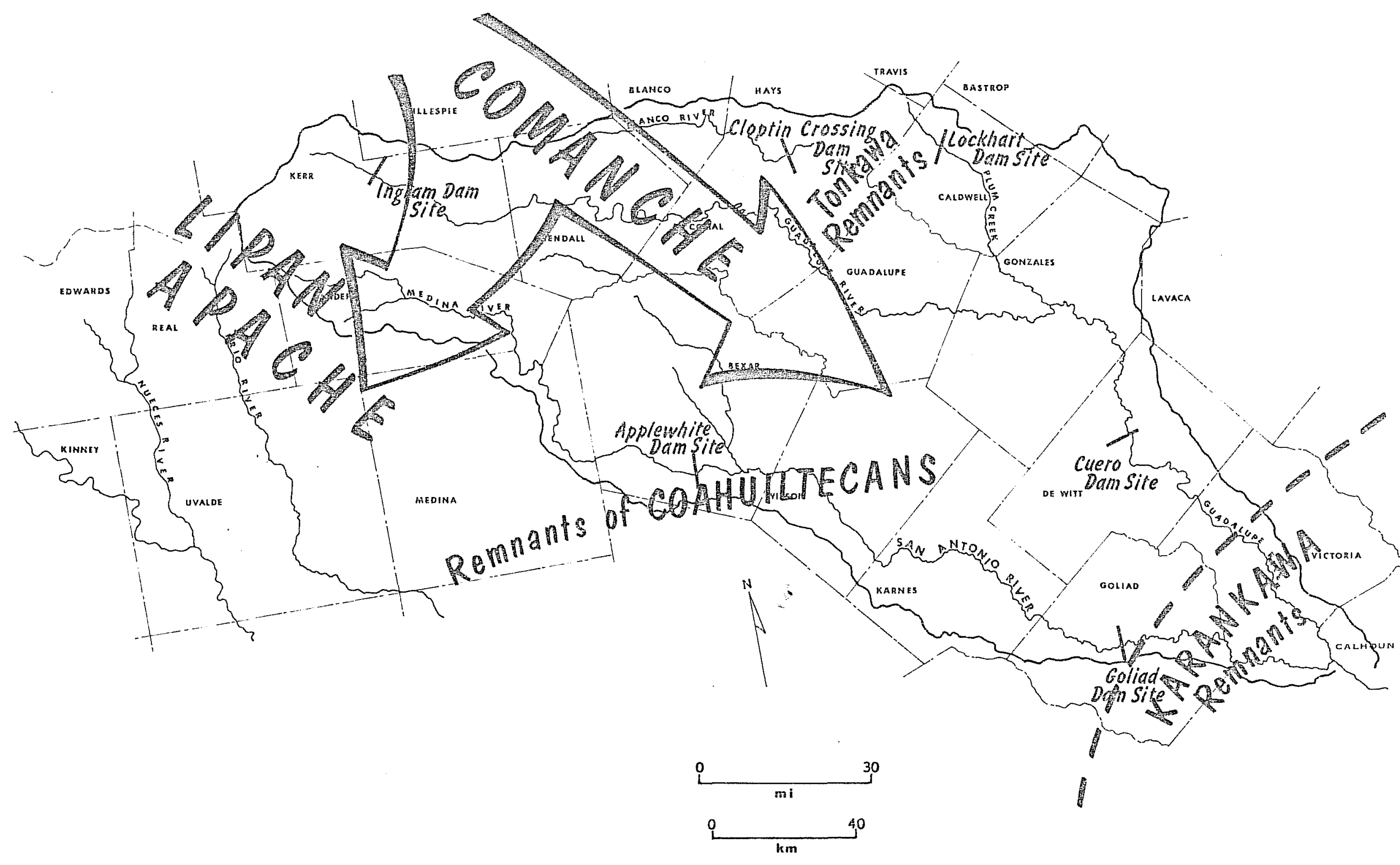

Figure 4. Locations of Major Indian Groups in the Study Area During the Eighteenth and Nineteenth Centuries. 
HISTORICAL SUMMARIES OF COUNTIES IN THE STUDY AREA

In this section we present general historical statements for each of the 17 counties in the study area. Incorporated in these summaries are comments on historical events, major historical personages, and "Western Frontier" aspects of each county. We are grateful to Cathrine McDowel1 of the Alamo Library for her assistance in this compilation.

\section{Bandera county}

Bandera County was created from a part of Bexar County in 1856 and was named for the Bandera Mountains which are situated in the northern part of the county. The first settlers to locate in the county were shingle makers who used the extensive cypress growth along the Medina River as the source of their raw materials. To man this industry a Polish settlement was formed. There was also a colony of Mormons that had settled here a year or so earlier under the leadership of E1der Lyman Wight.

Bandera County is the locality of one of Texas' most famous battlegrounds. Bandera Pass, a gorge 500 yards long and 125 feet wide, which cuts between the mountains that separate the Guadalupe and Medina Valleys, has been the scene of numerous battles dating almost since the earliest recorded Texas history. In 1720 General Bandera, under orders from the Spanish King, came here to drive out marauding Apaches who were threatening the small Spanish settlement at San Antonio. The battle lasted three days and resulted in the departure of the Apaches from that locality. The pass was also the site of a later battle in 1842 between Texas Rangers and Comanche Indians. The Texas Rangers were led by Captain John Coffee (Jack) Hays and included such personages as Ben McCulloch, P. H. Bell, Creed Taylor, and William A. (Big Foot) Wallace. The battle was indecisive, both sides withdrawing to recuperate. Numerous other smalier battles have been fought at this point.

Bandera Pass, as indicated by the name, has also long served as an important transportation route in the area utilized by settlers, Rangers, Indians, and the U.S. Army.

Prominant figures in the history of Bandera County have included Jose Policarpo (Polly) Rodriguez, noted gulde and scout with the Texas Rangers and U.S. Army, who settled on Privilege Creek where he organized a Methodist church (Polly's Chapel), Charles de Montel and John James, both prominent surveyors and leaders in this area. Camp Montel, at the head of Seco Creek, was established in 1862 as a ranger station for the Frontier Regiment, and was named for Charles de Montel.

*Compiled by Feris A. Bass, Jr. 
Bexar County

This was the first civil settlement in Texas and played a major part in Texas history; here we provide only a brief summary. Established in 1731 when 13 Canary Island families arrived in the area already occupied by the Villa de Bexar and the missions of San Antonio de Valero, San José y San Miguel de Aguayo, San Juan Capistrano, and Nuestra Senora de la Purisima Concepcion. These "Isleños" called their little settlement San Fernando.

From the establishment of the first mission, San Antonio de Valero (1718), until after the Civil War, there have been many conflicts among the varying peoples who have lived here: Spanish and Indians, Spanish and Mexicans, Mexicans and Texans, Confederates and Federals.

There have been 12 battles in the environs of San Antonio that have left their mark: Rosalie (1813), Alazan (1813), Medina (1813), Concepcion (1835), Grass Fight (1835), Battle of Bexar (1835), Alamo (1836), Council House Fight (1840), Woll Capture of San Antonio (1842), Salado (1842), Dawson Massacre (1842), and Adans Hill (1861). Skirmishes with Indians were common until the late $1800^{\prime} \mathrm{s}$.

All types of military establishments have been here, since the first presidial soldier from Spain until today's Army and Air Force.

The many different peoples who settled here have given Bexar County a cosmopolitan heritage that is a blending of Spanish, Indian, Mexican, French, German, American, Irish, Chinese, Negro, and other cultures and customs.

Caldwell county

The county was originally part of the DeWitt Colony (1824-1836). It was created from Gonzales in 1848 and named for Matthew Caldwe11, signer of the Texas Declaration of Independence, soldier, and Texas Ranger.

A major early event in the area that now comprises Caldwell County was the Battle of Plum Creek (in 1840), between the Comanches and Texans.

During the Civil War seven companies were furnished the Confederate Army by the county. It was during this period that a considerable growth in the cattle industry occurred and in 1868 the first "trail drive" (a herd owned by J. J. Meyers) was sent from the county.

The first railroad was built in the county by the Missouri, Kansas and Texas Rallroad in 1885. Industrialization followed the railroad and in 1893 a cotton oll mill was established, followed by a cotton compress in 1901. In 1922, iron ore was found along with lignite in the Iron Mound district. This was followed by the discovery of oil in the vicinity of Luling. 


\section{Calhoun County}

This county constituted part of De Leon Colony (1824), and was created from Victoria County and named for John $\mathrm{C}$. Calhoun of South Carolina. In 1685 René-Robert Cavelier, Sieur de La Salle, landed on the west shore of Lavaca Bay. The first location of Mission Nuestra Señora de1 Refugio in 1793 was north of the Guadalupe River near 1ts juncture with the San Antonio River.

In 1844, the town of Indianola was established as a port of entry for French and German colonists. It was the eastern terminus of the Indianola Railroad, completed in $1870^{\circ} \mathrm{s}$. The Mexican-Gulf Railroad had already been completed in 1861 from Lavaca to Victoria. Both became a part of the Southern Pacific system.

Indianola and Lavaca were captured by Federal troups in 1863 following the battle of Matagorda Bay. The only Civil War battle fought in Calhoun County was on Christmas Eve, 1863 at Norris Bridge. The port rivaled Galveston until its destruction by two hurricanes ten years apart (1875 and 1886). After the 1886 storm completely devastated the rebuilt town, it was abandoned.

Linnville, established in 1831 near the western end of the present causeway by Juan (John) J. Linn (a member of the De Leon Colony), was destroyed in 1840 by a Comanche raid that culminated in the Battle of Plum Creek in Caldwell County. The fugitives from this raid established the present town of Port Lavaca. Sylvanus Hatch, a sea-captain who brought many of the Stephen $F$. Austin colonists to Texas, had large land holdings in this area. The Hatch Family Cemetery is now part of the Port Lavaca Country Club grounds.

Comal county

Comal County, created in 1846 from Bexar and Travis Counties, was at the cross-roads of many of the early Spanish expeditions into the northern Frontier. Cabeza de Vaca is believed by some writers to have passed this way in 1635. Domingo Teran de los Rios inspected the area in 1691, as did Domingo Ramon in 1716 whfle on his way to establish missions in east Texas. He was quickly followed by Marquis de Aguayo in 1720. Fedro de Rabago y Teran proposed a mission for the area in 1754. Fray Mariano Francisco attempted to transfer the Mission San Francisco Kavier de Horcasitas from the San Marcos to the Guadalupe River at the present site of New Braunfels. In 1756 the unofficial mission of Nuestra Señora de Guadalupe was established here to serve neophytes of the abandoned mission on the San Marcos River. The mission was withdrawn in 1758 to avoid destruction by the Comanches.

New Braunfels, (county seat) founded by and named for Prince Carl of Solms-Braunfels, was a settlement for colonists from Germany. It was the home of Ferdinand Lindheimer (1801-1879), editor of the oldest German newspaper in Texas and father of Texas botany. German is still spoken 
by many citizens. In 1848 New Braunfels Academy was established.

John O. Meusebach, Pastor L. C. Evenberg, Dr. Theodore Koester, and Herman Seele were among the prominent early settlers.

Dewiet county

DeWitt County was created from Gonzales, Victoria, and Goliad Counties in 1846 and was named for Green $C$. DeWitt, the second impressario to be authorized by the Mexican government to colonize in Texas. This area was well known by early Spaniards. Alonzo de León led an expedition here in 1689 in search of the French Fort St. Louis. Martin de Alarcón and Pedro de Rivera were both here on inspections in the early part of the 18th century.

James Kerr, DeWitt's agent, brought the first settlers here in 1825 . The pioneer settlements were between McCoy's Creek and Cuero Creek and between Irish Creek and the Guadalupe River. Germans began to immigrate to the area shortly after the Battle of San Jacinto and by 1860 comprised the majority of the population of the county.

In 1873 the Galveston, Harrisburg, and San Antonio Railroad reached Cuero. This brought about a boom in the development for the community which lasted unti1 1906 when the railroad was extended to San Antonio.

The first county seat was Cameron but was moved to Clinton in 1850 , and then across the river to Cuero in 1876. The present day population is a mixture of descendents of DeWitt colonists and Germans who immigrated to Texas. Many residents of Indianola moved inland after the hurricanes of 1875 and 1886 , bringing their houses with them which they had dismantled and moved by ox cart and then reassembled at their destination.

DeWitt County was the scene of one of the most bitter and prolonged of early Texas feuds, that between the Suttons and the Taylors, which lasted from 1867 to 1875 and resulted in the deaths of many Suttons, Taylors, and their followers.

Several well-known private schools served this area during, and for some time after, the Civil War.

\section{Goliad county}

Goliad County is one of the original counties of Texas having been established in 1837 and named for the municipality of Goliad that was already in existence. The area in which this county is situated had long been the scene of Spanish activity in Texas. Cabeza de Vaca is believed to have crossed the county in his travels in 1535. La Salle is believed also to have crossed the county in his explorations in 1685 . However, actual settlement did not begin until 1749 when the Spanish 
moved the presidio and missions of La Bahia, Nuestra Señora del Espiritu Santo de Zuniga and Nuestra Señora de Loreto to the site of Santa Dorotea on the San Antonio River. In 1754 Nuestra Señora del Rosario was established four leagues southwest of La Bahia.

This was one of the three areas of Spanish occupation when the Americans began to enter Texas. One of the first of these entries was the Gutierrez-Magee Expedition which seized the presidio at La Bahia, to be besleged there by the Spanish governor of Texas, Manuel Salcedo, until the latter was forced to withdraw to San Antonio. In 1821 James Long captured the fort.

Some of the first steps by the Anglo-Americans toward the Texas Revolution were taken here when forces under Ben Milam and George Collinsworth drove the Mexican garrison out of the Presidio. But, the most famous of the military events that occurred at this locality was the defeat and massacre of the Texas Army under the command of James Fannin by General José Urrea in 1836.

Following the Goliad massacre the area was deserted until 1840 when Anglo-American colonization was resumed, but on the opposite slde of the river from the Spanish town.

Almost adjacent to La Bahia is the site of the birthplace of General Ignacio Zaragosa, the Mexican military leader who defeated the French forces at Puebla, Mexico, in 1862 .

Aranama Institute (Presbyterian) and Paine Female Institute (Methodist) were established in the $1850^{\circ} \mathrm{s}$ and were educational centers for the surrounding area for many years.

Gonzales county

Part of the colony of Green $C$. DeWitt, the county was named for Rafael Gonzales, a governor of Coahuila and Texas. It was one of the original counties of the Republic of Texas.

The first site selected by James Kerr for the capital of DeWitt's Colony in 1825 was Kerr"s Creek near the junction of the Guadalupe and San Marcos Rivers. In 1826 this was destroyed by Indians. Relocated on the east side of the Guadalupe River below the juncture of the streams, the settlement became the town of Gonzales.

On October 2, 1835 a troop of Mexican soldiers arrived near Gonzales demanding surrender.. of the cannon that had been given the settlers some years before as defense agafnst Indians. The settlers refused with the challenge "Come and Take It", thus creating one of the events that initiated the Texas Revolution. It was in this same area that General Sam Houston organized the Texan Army and began his strategic withdrawal that culminated in the Mexican defeat at San Jacinto in 1836. 
There are remains of two old forts at Gonzales and somewhere in the Guadalupe River lies the cannons Sam Houston ordered sunk when the retreat began.

Prominent early families were: Braches, Chenault, Eggleston, Dickinson, Reese, Pilgrim, Kennard, Ponton, Davis, Sumwalt, Rokernot, Putnam, Bennett, and DeWitt.

Guadalupe county

The county was created in 1846 from Bexar and Gonzales Counties and was named for the Guadalupe River that almost bisects it.

Seguin, an important town in the $1840^{\prime}$ s, was named for the Seguin family of San Antonio, but was first known as Walnut Springs. Several historic homes and sites are identifled by State Historical Markers.

The county was a center of activities of early frontier battalions and Ranger Companies since a major Indian trail from west Texas to the coast passed through it. In 1834 this activity became so intense that settlers were forced to withdraw to Gonzales for protection.

From 1837 to 1839 unclaimed land in the county was granted to veterans of the Texas Revolution and encouraged the rapid settlement of the area during these years.

Between 1839 and 1845 residents of the county participated in many fights with Indian marauders and Mexican invaders. The last Indian raid into the county occurred in 1885 .

Major early families included: Nei11, Louis, Smith, West, Rector, Sowel1, Ireland, Hollamon, Nichols, McCulloch, Day, Seguin, Navarro, Herron, Turner, Dale, Dickinson, Baker, Branch, and Montgomery.

Hays County

Created in 1848 from Travis County, the county was named for John C. (Jack) Hays, renowned as a leader of the Texas Rangers.

In 1755 the San Xavier missions and presidio were moved from their original 1746 location on the San Gabriel River in an unsuccessful attempt to relocate them on the site of present-day San Marcos. In 1808 settlers from Mexico, under the leadership of Felipe Roque de Partilla established the Villa de San Marcos de Neve in the same area, but by 1812 the colony was abandoned. In the early $1830^{\prime} \mathrm{s}$, the Mexican government granted large tracts of land to Juan Veramend1, T. J. Chambers, and Juan Vicente Campos. These embraced the San Marcos area and from them have come most of the land grants and deeds now in effect.

After Texas became part of the United States in 1846, this section of the state began to develop rapidly. Communities sprang up, and churches and schools were established. One group of settlers built their homes 
along a road west from San Marcos following the foothills of the Balcones Escarpment. This community is still known as Stringtown and some of the original houses are still in use.

Among prominent early families were: McGehee, Moon, Merriman, Sessom, Burleson, Pitts, King, Mathews, Kone, Malone, Combs, Kyle, Sowe11, Erhard, and Nance.

Karnes county

The county was created in 1854 from Bexar and Goliad Counties and was named for Henry $W$. Karnes. Helena was the first settlement (1852) and county seat. In 1885 the railroad by-passed Helena, and a new town, called Karnes City, was established near the rallroad. This became the county seat in 1894 .

Helena was the center of the "Cart War" in 1857 between freighters, and became a hideout for outlaws and rustlers.

Panna Maria (1854) is the oldest Polish settlement in the United States and was the center from which other Polish towns were established. St. Joseph's School (1868)' is considered to be the first Polish private school in the United States and its building now houses an historical society museum.

Two crossings of the San Antonio River, near Hobson and Falls City, were used by Indians on their trails to the coastal areas.

A major uraniun discovery in Texas was near Falls City, and a uranium mining-refining plant now is located nearby.

There are several old ranching families in the county, including the Lytles and Toms.

Kendall county

Created in 1862 from Bexar, Comal, and Blanco Counties, this county was named for George Wilkins Kendal1, a founder of the sheep industry in Texas.

Boerne (county seat), Comfort and Sisterdale were established in the late $1840^{\prime} \mathrm{s}$ and early $1850^{\prime} \mathrm{s}$ by members of the German colonies who had come into the area during the early $1840^{\circ} \mathrm{s}$. Many of these did not want to secede from the United States and join the Confederacy. A number of these Union sympathizers were killed in the Battle of the Nueces in 1862.

Prominent families of the county include: Altgelt, Zink, Degener, Steves, Faltin, Stieler, Ransleben, Schleicher, and Faust.

Kerr county

Created in 1856 from Bexar County, the county was named for James Kerr. The first settlement in the area (1840) was by a group of shingle 
makers; this later became the town of Kerrville, the county seat.

Camp Verde, just inside the line between Bandera and Kerr Counties, was established by the U. S. Army in 1855. In 1856 it became home for the camels the Army brought into Texas through the port of Indianola, Calhoun County. The experiment of using camels as pack animals across the deserts of the southwest was just getting underway when the Civil War erupted and all plans were cancelled.

Descendents of many of the early German families who first settled the area still live there. Prominent families include; Schreiner, Real, Stieler, and Reese.

\section{Medina County}

This county was created from Bexar County in 1848 and named for the Medina River that angles across the northeastern part.

First settlement occurred in 1844 when Henri Castro established the capital of his colony and named it Castroville. The town still shows its Alsatian (French-German) heritage in its architecture and traditions; headstones in the old cemetery on a hill just west of town bear testimony of the origins of those burfed there.

A few miles north of D'Hanis is the site of Fort Iincoln, established by the U. S. Army in 1849 and named for Captain George Lincoln killed at the battle at Buena Vista during the Mexican War.

Among prominent early families are: Pingenot, Tondre, Huth, Haass, Enkin, Habe, Lesberg, Battot, De Montel, and Wipff.

uvalde county

Created from Bexar County in 1850, the county is named for Captain Juan de Ugalde, leader of Spanish forces in many encounters with Indians.

Near present day Montell is the site of Mission Nuestra Señora de la Candelaria de Cañon (1762), companion to Mission San Lorenzo de 1a Santa Cruz which is a few miles north in Edwards County near Camp Wood. In this same area was the home of John R. Baylor, famous Texas Ranger captain and Confederate General.

Many important outposts and camps for soldiers and Rangers were in the county, including Fort Inge (1849), Camp Sabinal (1856), and Camp Nueces (1862). An important historic community in Utopia, in the northeastern part of the county. Founded as Waresville in 1852, there are many old structures (some with State Historical Markers) and several cemeteries dating from the middle and late 19th century. The Utopia Methodist Church (1890) is sti11 being used and behind it is the grove of pecan trees where "camp meetings" have been held for over a hundred years. 
A major character of the Texas frontier of the late 19th century was sometimes-sherifs, sometimes-badman, J. $\mathrm{K}$. "Wing" Fisher of. the Uvalde area.

\section{Victoria County}

This county was the capital of the colony of Martin De Leon, the only successful Mexican colonizer, and was named for Guadalupe Victoria, first president of the Republic of Mexico. It was one of the original counties of the Republic of Texas.

On the west bank of Garcitas Creek in 1685, René--Robert Cavelier, Sieur de La Salle, established Fort St. Louis. The reputed site is on private property. In $1721-22$ the Spanish built the Presidio of Loreto on the same site of Fort St. Louis, and the Mission of Nuestra Señor del Espiritu Santo de Zuniga across the Garcitas on the east bank. In 1726 both the presidio and mission were moved to a location on the Guadalupe River now known as Mission Valley near Victoria. Again in 1749, both were moved to sites on the San Antonio River near Goliad.

Victoria was headquarters of the Army of the Republic of Texas for some time after San Jacinto, and a Confederate army camp was located just north of the town.

Many early settlers are buried in Memorial Park and Evergreen Cemetery in the town of Victoria. Several fine homes of both ante-bellum and Victorian periods are in existence and some are still being used by descendants of original owners.

Prominant persons associated with the area are: Martin De Leon, Juan (John) J. Linn, Victor Rose, James A. McFaddin, Al McFaddin, Judge Alexander Phillips, the O'Connor family, the Wilder family, Abel Seymour Cunningham, Captain James B. P. January, and Peter Tea1.

\section{Wilson County}

The county was created from Bexar and Karnes Counties in 1860 and was named for James $C$. Wilson. Originally, the area contained "ranchos" of Canary Islanders who settled San Antonio in 1731. There is an old cemetery at Floresville of many of these families, including Flores, Barrera, Arocha, and Seguin. On the banks of the San Antonio River near Floresville is the site of old Rancho de las Cabras, a "rancho" of Mission Espada in San Antonio, and now on the National Register of Historic Places.

Sutherland Springs, located on the Cibolo Creek, was established by Dr. John Sutherland at the location of mineral springs. It was a popular health spa around the turn of the century. Also located on the Cibolo Creek is "White Hall", built by the Polley family who had come to Texas with Austin's Colony. 


\section{GENERAL COMMENTS ON \\ ETHNIC AND REIIGIOUS GROUPS \\ OF THE REGION*}

The Spanish began populating Texas in the early $1700^{\circ} \mathrm{s}$ by establishing missions and presidios to Christianize and educate the Indians. In 1718 the Mission of San Antonio de Valero (later known as the Alamo) was established with the Presidio San Antonio de Bexar. other missions were built but San Antonio's actual growth began with the establishment of the villa of San Fernando de Bexar. This civil settlement was founded by Canary Islanders on June 21, 1731. In 1749 Mission Nuestra Señor del Espiritu Santo de Zuniga and Presidio Santa Maria del Loreto de la Bahia were established at Goliad. Other missions and presidios were set up in Victoria and Uvalde counties.

German immigration to this part of Texas was very heavy in the $1840^{\prime} \mathrm{s}$. One of the most noted settlements was New Braunfels in Comal County. In 1844 Prince Carl of Solms-Braunfels brought three shiploads of German immigrants to Texas. On the Texas coast they set up a tent village known as Carlshafen, but in 1845 most traveled to the site of New Braunfels and laid the foundation for one of the most solid German towns to be established in Texas. They brought with them thelr Catholic and Lutheran religions and churches were soon bullt.

Other German immigrants settled in areas such as San Antonio, Boerne, Comfort, Yorktown, and Kerrville. Two unique German colonies were set up in Kendall County. Led by a group of German university scholars, the colonies of Bettina and Sisterdale were organized along communal lines. This experiment falled and most of the colonists moved on to other German settlements.

The Reverend Leopold Moczygemba is given credit for the first Polish migration to South Central Texas. In 1841 he was sent to serve the German settlement of New Braunfels. In 1854 he established the colony of Panna Maria which was populated by Folish Catholics. San Anconio, Bandera, Yorktown, and Meyersville were also settled by Polish Imigrants.

In the early $1800^{\prime} \mathrm{s}$, scores of Anglo-Americans came to Texas seeking Mexican land grants. Green $C$. DeWitt was signiflcant in obtaining these land grants in our area of interest and responsible for such settlements as Cameron, CIInton, Meyersville, Yorktown, and Seguin. Calhoun County's first Anglo-American colony was Linnville. Established in 1831 it was soon raided by Comanches. The survivors moved to another site and set up the town now known as Port Lavaca. Other sites populated by Anglo-Americans include San Antonio, Gollad, Lockhart, San Marcos, and Kerrville. Methodist, Baptlst, Lutheran, Catholic, Presbyterian and Episcopal churches were set up in the late $1800^{\prime} \mathrm{s}$ in many of these settlements.

other significant ethntc and religious groups also populated this section of Texas. Spanish settlers began moving into Uvalde county in the late $1700^{\circ} \mathrm{s}$. In 1824 Martin De Leon obtained a land grant

*Compiled by Lynn Highley 
and settled several Mexican families at a site later known as Victoria. Mexicans also settled in Goliad and San Antonio.

The towns of Castroville and D'Hanis were established by Alsatian families in the $1840^{\prime} \mathrm{s}$. Most of the families were Catholic. Mormons settled several areas in Texas. In 1854 a Mormon settlement was set up in Bandera. Other ethnic groups included Irish and ScotchIrish-English settlers moving into Goliad County in the $1830^{\prime} \mathrm{s}$ and Italian immigrants in San Antonio in the late $1800^{\prime} \mathrm{s}$.

\section{Bibliography for Ethnic and Religious Groups}

Crook, Cornelia

The Stany of D'Hanis. Pamphlet on file at the University of Texas at San Antonio, Institute of Texan Cultures. n.d.

Didear, Hedwig Kre11

A History of Karnes County and Oed Helena. San Felipe Press, Austin. Jenkins Publishing Company. 1969.

George, C. D.

Calhoun County. Typed page from Port Lavaca Historical Society, on file at University of Texas at San Antonio Institute of Texas Cultures. n.d.

Grimes, Roy (Editor) 300 years in Victoria County. Victoria Advocate Publishing Company. 1968.

Haas, Oscar

History of New Braunóels and Comal County. Texas: 1844-1946. The Steck Company, Austin, 1968.

Hansen, Harry (Editor)

Teras: A Guide to the Lone Star State. New York Hastings

House. 1969.

Institute of Texan Cultures, San Antonio

The Czech Texans. 1972.

The French Texans. 1973.

The German Texans. 1970.

The Italian Texans. 1973.

The Indian Texans. 1970.

The Jewish Texans. 1974.

The Mexican Texans. 1971.

The Norwegian Texans. 1970.

The Polish Texans. 1972.

The Spanish Texans. 1972.

The Syrian and Lebanese Texans. 1974.

Murphee, Nel1ie

A Histony of Dewitt County. R. W. Shook, Victoria College. 1962. 
Seele, Herman (Compiler)

A Short Sketch of Comal County, Texas. Zeitung Press, New Braunfels. 1885.

Webb, Walter Prescott (Editor)

The Handbook of Texas, Vols. I, II. The Texas State Historical Assoctation, Austin. 1952.

Weisinger, S.R.

Victoria County. Typed page on Victoria County from Victoria Historical Society. n.d.

\section{ARCHITECTURE AND STYLES*}

Spreading across the breadth of central Texas from the Gulf of Mexico at San Antonio Bay, to the upper reaches of the Nueces River across the breaks of the Balcones fault, the architectural record of European man's "colonization" of this portion of the New World is evident in a strong, indigenous architectural style. Born of necessity, guided by availability of materials and climate, and influenced by their own background, the early pioneers built strong, simple, and above all, functional, shelter for themselves and their families.

The construction techniques range from log cabins to adobe walls, split shake roofs of native cypress, combinations such as timberand-stone and post-and-adobe, usually faced with a local lime plaster for durability.

The first and most pervading European Influence came with the Spaniards by way of Mexico in the $18 \mathrm{th}$ century. Thick stone and adobe walls, limited openings shuttered against the heat and cold, and secluded patios hidden from the streets were the stylistic labels of the Spanish buildings. More elaborate church architecture carried with it the typical Romanesque influence of Spain in the 12 th and 13 th Centuries, and the $14 \mathrm{th}$ Century Gothic. Moorish overtones, as seen in the charming entrance portal of the small chapel at Espada Mission, south of San Antonio, are reminders of the Moorish occupation of Spain. Influenced by their lives in Spain, the colonizing padres and conquistadors built their churches in faithful detail to extend their architectural style into the new world and particularly Texas.

With the coming of the 19th Century, south central Texas saw an entirely different style of architecture brought in by the arriving immigrants from Germany, Alsace-Lorraine, and Poland. These included steep pitched roofs, native limestone combined with wood posts, and wide porches created by an extension of the simple gable-ended roofs. Wood-work details embellished the exteriors with intricate, perforated scrollery, outlining the porch columns and extending up the rake of the gable roofs. Finely detailed doors and windows with shutters, extended the display of wood-working craftsmanship.

New Braunfels was one of the centers of German architectural influence which spread into the hill country of the Edwards Plateau. 
Castroville with its stuccoed inns and stone homes is a concentration of Alsatian influence and atmosphere, resulting from the early settlement along the Medina River of immigrants under the leadership of Henri Castro.

French architectural design influence, although much neglected, is still quite evident in the cosmopolitan mixture for which San Antonio is widely famous. The lovely details of the old Ursuline Academy buildings reveal the New Orleans background of these intrepid sisters. French Mansard roofs, such as on the home formerly located at Elm Street and $E$. Houston, are seen in the detalling of many fine old structures.

Classlc influences were strong in the mid-19th century, particularly in the public buildings in San Antonio. The original Menger Hotel, south of the Alamo on Alamo Plaza, presented a simple classic facade which has since been modified and further embellished. Greek reviva1, so popular in the east at this time, was reflected in the stately colonade of the City Market bullding then located on $W$. Market Street, but now gone.

Victorian flamboyancy appears in many fine old structures in the San Antonio area such as Schultze's Store, the Steves Homestead, and several others, particularly in the King William area.

Typical examples of these architectural styles are listed by county below:

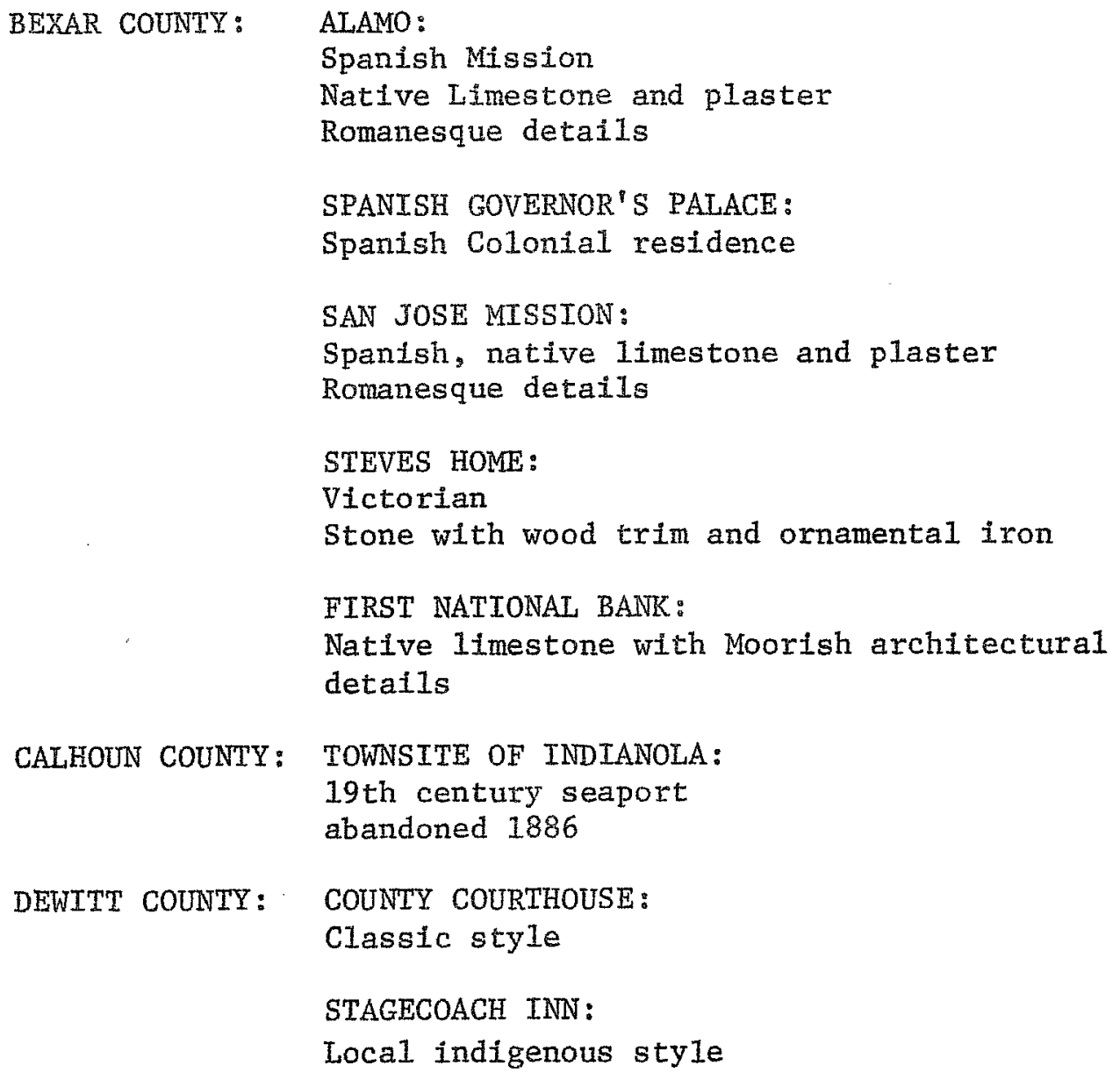


GOLIAD COUNTY: MISSION LA BAHIA AND PRESIDTO LA BAHIA:

Spanish (National Historic Landmark)

COUNTY COURTHOUSE:

Alfred Giles, Architect

Classic details; native Iimestone

GONZALES COUNTY: COUNTY COURTHOUSE:

J. Riely Gordon, Architect

Romanesque revival

COMAT COUNTY: COUNTY COURTHOUSE:

J. Riely Gordon, Architect

Classic, of limestone

KARNES COUNTY: COUNTY COURTHOUSE:

Romanesque, with Mansard roofs

VICTORIA COUNTY: VICTORIA CITY HALI:

Classic Style with Mansard roofs

and cupola

ESPIRITU SANTO MISSION:

Spanish; 1726

OLD DAM and ACEQUIA nearby

We also provide the following brief list of references dealing with the architecture of the region:

Alezander, Drury B.

1966 Texas Homes of the 19th Century. Publication No. 1 Texas Architectura1 Survey, University of Texas Press, Austin.

Anerican Institute of Architects, San Antonio Chapter 1963 Historic San Antonio 1700-1900. San Antonio.

Bracken, Dorothy $\mathrm{K}$. and Maurine $\mathrm{W}$. Redway 1956

Early Texas Homes. Southern Methodist Press, Dallas.

Briggs, Alton 1971

Archeological Resources in the Texas Coastal Lowlands and Littoral. Texas Historical Survey Commission. Austin.

Brooks, Charles, M. Jr. 1936 Texas Missions. Dealey and Lowe, Dallas.

Corner, William 1890

San Antonio De Bexar. Bainbridge and Corner, San Antonio.

Gideon, Samuel 1942

Architecture and Culture of Early Texas. Unpublished. 
Greer, John W. 1967

A Description of the Features, Straigraphy and Artifacts from Archeological Excavations of the Alamo. State Building Commission Archeological Program, Report 3.

Judson, Mary Carolyn 1972

Alfred Giles. Trinity University Press, San Antonio.

Ransleben, Guido 1954

A Hundred Years of Comfort. Naylor Co., San Antonio.

Robinson, Willard

1974 Texas Public Buildings of the 19th Century. Publication No. 2. Texas Architectural Survey University of Texas Press. Austin.

San Antonio, City of

1973 Missions of San Antonio, A Plan. Comprehensive Plaming Division. City of San Antonio.

1972 San Antonio Renenal Program. San Antonio Historic Survey, Survey and Appendix. City of San Antonio.

Sanford, Trent E. 1950

Architecture of the Southwest. W. W. Norton and Company. New York.

Talbot, Zora M. 1961

Stringtown. University of Corpus Christi Press.

Tunne11, Curtis D. and W. W. Newcomb, Jr.

A Lipan Apache Mission. Bulletin, Texas

Memorial Museum, Bulletin 19. 


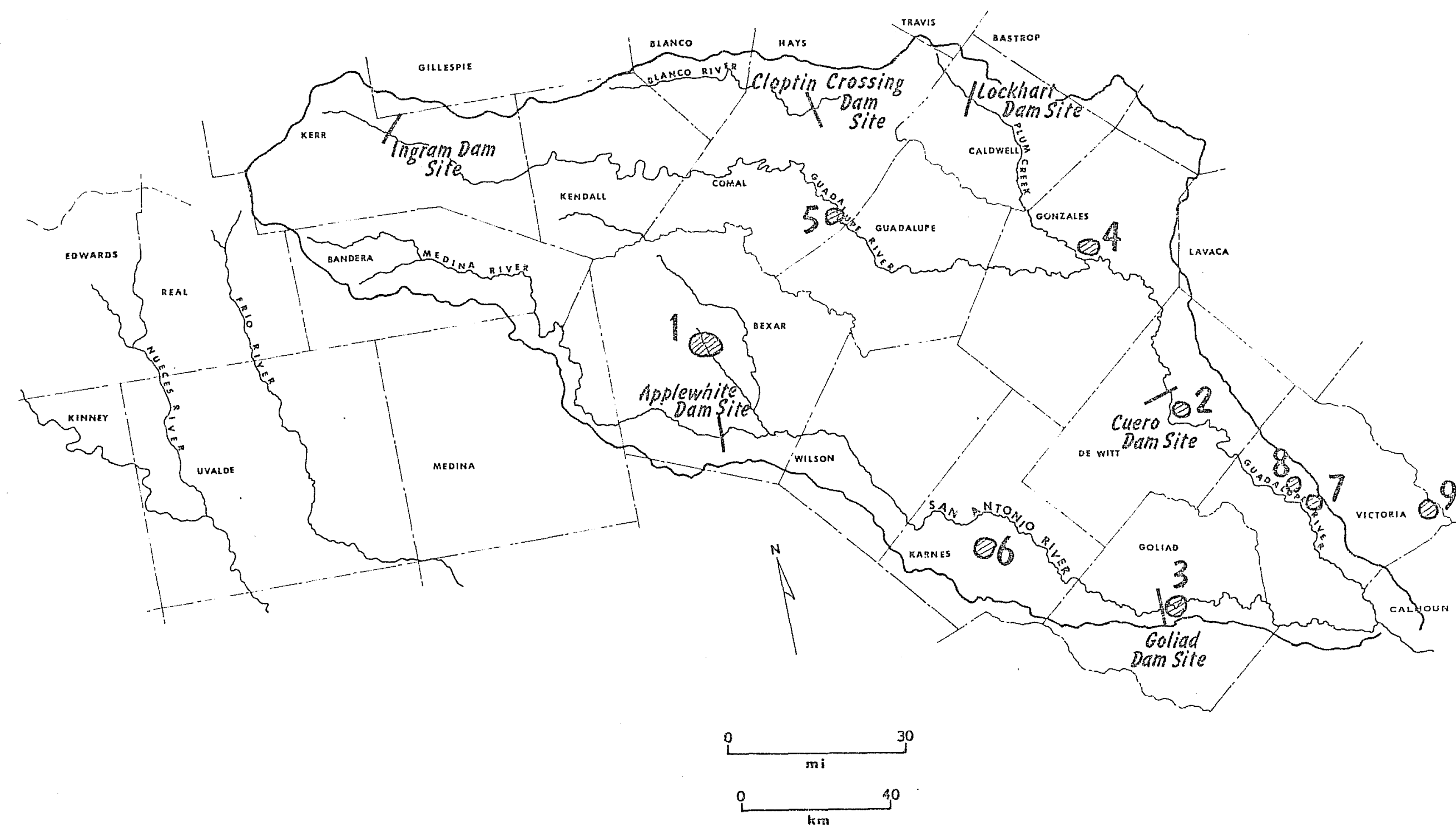

Figure 5. Locations of Significant Architectural Resowrces in the Study Area. 1. San Antonio; 2. Cuero; 3. Goliad; 4. Gonzales; 5. New Braunfels; 6. Karnes City; 7. Victoria; 8. Espiritu Santo Mission; 9. Fort Saint Louis. 


\section{CONCLUDING COMMENTS}

In this report, we have provided a general inventory of cultural resources in the basins of the San Antonio and Guadalupe Rivers. In reviewing the region's rich and varied cultural inventory, we have summarized data relative to history, Indian cultures, archaeology, axchitecture, and ethnic and religious groups.

We have placed a somewhat greater emphasis in this report on an evaluation of the archaeological resources. It is clear that we know a good deal about the archaeology of some counties, and almost nothing about others. The same can be sajd about historical resources; records for some counties are lengthy and detailed, while only meager information is available in other counties. In general, we still know far too little about the archaeological-historical remains in this 17-county area. Yet, these resources are being rapidly depleted through urban and Industrial expansion, the spread of housing and resort developments, and the depredations of relic collectors and vandals. Numerous historic and prehistoric archaeological sites have been destroyed and their loss is irreplaceable.

To date, only two major reservoirs have been constructed in the study area. In the case of Canyon Reservolr (Comal County), an extensive archaeological survey and salvage program was carried out (Johnson, Suhm and Tunnel1 1962). On the other hand, Lake Medina (Medina County) was built many years earlier and was developed without benefit of archaeological-historical inspection. Federal and State legislation now acts to ensure that archaeological and historical resources will be evaluated, and the impact of their loss mitigated, prior to dam construction.

In the present report, we have mentioned two planned reservoir areas, Ingram and Cuero, within which archaeological survey has already been conducted. The other four reservoirs (cloptin Crossing, Applewhite, Goliad, and Lockhart) are still in the planning phases. We strongly suggest that archaeological-historical assessments be done of these areas in the near future, so that the resulting data can be of value in the planning and project evaluation procedures. 


\section{BIBLIOGRAPHY*}

Briggs, Alton $\mathrm{K}$.

1971 Archeological Resources in the Texas Lowlands and Littora1. Texas Historical Survey Committee and Texas Water Development Board.

Campbe11, T. N.

1962 Excavations at the Morhiss Site, Victoria County, by the University of Texas, 1938-40. Paper presented at the Annual Meeting of the Texas Archeological Soclety, Victoria.

Collins, Michael B.

1970 On the Peopling of Hitzfelder Cave. Bulletin of the Texas Archeological Society 41: 301-304.

Crawford, Daymond D.

1971 An Archeological Reconnaissance of Ecleto Creek Watershed South Centra1 Texas. Texas Archeological Salvage Project Survey Report 8.

Fox, Anne A.

1974 An Archaeological Survey of the Nichols Creek Channel Modification, Karnes County, Texas. Center for Archaeological Research. The University of Texas at San Antonio. Archaeological Survey Report 5.

Fox, Daniel E., Robert J. Mallouf, Nance $0^{\prime M a 1 l e y ~ a n d ~ W i l l i a m ~ M . ~ S o r r o w ~}$

1974 Proposed Cuero I Reservoir. Texas Historical Commission and Texas Water Development Board. Archeological Survey Report 12 .

Fritz, Gayle

1972 Pilot Archeological Field Survey of Cox Bay, Calhoun County, Texas. Matagorda Bay - Estuarine Resource Management Study. Environmental Planning Division of Texas General Land Office.

Ha11, Grant D.

1974 Leona River Watershed, Uvalde County, Texas: An Archeological and Historical Survey of Areas Proposed for Modification. Texas Archeological Survey, Research Repoit 37.

*Itens cited in text 
Hester, Thomas Roy

1971 Archeological Investigations at the La Jita Site, Uvalde County, Teras. Bulletin of the Texas Archeological Society 42: 51-148.

Hester, Thomas R, Feris A. Bass, Jr, and Thomas C. Relly

1975 Archaeological Survey at Portions of the Comal River Watershed, Comal County, Texas. Center for Archaeological Research. The University of Texas at San Antonio, Archaeological Survey Repori 6.

Hester, Thomas Roy and Robert C. Parker

1970 The Berclair S1te: A Late Prehistoric Component in Goliad County, Southern Texas. Bulfetin of the Texas Archeological Society 41: 1-24.

Hsu, Dick Ping and Ronald W. Ralph

1968 An Appraisal of the Archeological Resources of Cibolo Reservoir. Wilson County, Texas. Archeological Survey Report No. 1. Texas State Building Commission and Texas State Water Development Board.

Jackson, A. T.

1938 Picture-Writing of Texas Indians. University of Texas Publication 3809.

Johnson, Leroy, JY, Dee Ann Suhm, and Curtis D. Tunnell

1962 Salvage Archeology of Canyon Reservoir: The Wunderlich, Footbridge and oblate Sites. Texas Memorial Museum. Bulletin 5 .

Newcomb, W. W. Jr。

1961 The Indians of Texas. University of Texas Press, Austin.

Orchard, C.D.

1974 Letter on Fort Wah1. On file, The Univensity of Teras at San Antonio, Center for Archaeological Research.

Patterson, Patience $\mathrm{E}$.

1974 Upper San Marcos River, Watershed, Hays County, Texas: An Archeological Survey of Areas Proposed for Modification. Texas Archeological Survey, Research Report 42. 
Roberson, Wayne

1972 The Study of Extinct Rural Commulties in the United States. A Test of Feasibility. M. A. Thesis, University of Texas at Austin.

Shafer, Harry J.

n.d. Archeological Survey of the Blieder's Creek Reservoir. Manuscript on file: Texas Archeological Survey, Austin.

Skinner, S. A.

1974 Prehistoric Settlement of A Natural Area. PhoD. Dissertation, Southern Methodist University.

Stephenson, Robert L.

1949 Archaeological Survey of Canyon Reservolr on the Guadalupe River, Comal County, Texas. On file, Smithsonian Institution, River Basins Survey, LincoIn, Nebraska.

Suhm, Dee Ann

1958 A Review of Central Texas Archeology. Bulletin of the Texas Archeological Society 29: 63-108.

Suhm, D. A., A. D. Krieger, and E. B. Jelks

1954 An Introductory Handbook of Texas Archeology. Bulletin of the Texas Archeological Society 25. 